\title{
Temperatures of Formation of a Metahalloysite Deposit at Djebbel, Debbagh, North Eastern-Algeria
}

\author{
F. Assassi ${ }^{* 1}$, C. Renac ${ }^{2}$ L. Djabri ${ }^{3}$ and A. Hani ${ }^{4}$ \\ ${ }^{1}$ Laboratoire de Géologie, Faculté des Sciences de la Terre, Université Badji- Mokhtar, BP.12, Annaba 23000, Algérie \\ ${ }^{2}$ Département de Géologie -UMR 6524 CNRS, Université Jean Monnet Saint Etienne 42023, France \\ ${ }^{3}$ Laboratoire de L'Environnement, Faculté des Sciences, Université Université Badji- Mokhtar, BP.12, Annaba 23000, \\ Algérie \\ ${ }^{4}$ Laboratoire de Géologie, Faculté des Sciences de la Terre, Université Badji-Mokhtar, BP.12, Annaba 23000, Algérie
}

\begin{abstract}
Mount Debbagh (Djebel Debbagh) is part of the neritic Constantinois Formation located in northeastern Algeria. This Formation consists of autochthonous limestones units varying in age from Jurassic to Cretaceous that contain autochthonous Aptian to Cenomanian limestones deposited in seawater. During diagenesis, temperatures of limestones varied from 50 to $130^{\circ} \mathrm{C}$ as measured by fluid inclusions and determined by stable-isotopes $(\mathrm{C}, \mathrm{O})$. These temperatures and stable-isotope values are consistent with the diagenetic evolution of a sedimentary pile with small influxes of meteorichydrothermal fluids, mixtures of saline fluids within a neotectonic framework. Karsts filled with detrital and neoformed clay deposits were located below an unconformity that was dated at Lutetian times. The largest karst is mainly composed of metahalloysite, whereas other karsts contain kaolinite, illite and illitesmectite detritus from nearby clastic units. In the central part of the largest karst, metahalloysite is associated with minor sulphates due to dominant weathering below $40^{\circ} \mathrm{C}$ (presumably between 15 and $25^{\circ} \mathrm{C}$ ) by coastline meteoric-fluids with a $\delta^{18} \mathrm{O}$ value ca. $-2 \% \mathrm{~V}$-SMOW. These low temperatures do not correspond to previous interpretations that considered the thermal system to be at elevated temperatures $\left(>75^{\circ} \mathrm{C}\right)$ associated with neotectonics and/or hot-spring activity. Isotope exchange experiments with different size fractions of pure metahalloysites, with no expandable capacity indicate that they do not exchange hydrogen isotopes over 24 months for a temperature of $23^{\circ} \mathrm{C}$. These results used together with kaolinite oxygen and hydrogen fractionation suggest that halloysite to metahalloysite transformation occurred within a temperature range between 25 and $40^{\circ} \mathrm{C}$.
\end{abstract}

Key words: karst, metahalloysite, stable isotopes, exchange experiments, paleotemperatures.

\section{INTRODUCTION}

Massive kaolinite group mineral deposits are rare in North Africa. The Djebel Debbagh (Fig. 1) area in northeastern Algeria has the second largest kaolin deposits in North Africa. To explain the origin of the clay deposits previous studies concentrated on structural, crystallographic and chemical analyses of a series of karsts in the area, containing mixtures of clays minerals such as kaolinite, halloysite and illite. These non-isotopic studies on the genesis of the clay minerals have suggested either hypogene, hydrothermal models [1] or supergene weathering origin [2-4]. Field observations and scientific data agree that the kaolin ore was ultimately derived by weathering of the original detrital clays minerals, but that the neotectonism in the area did not significantly modify the original form of the deposits.

This study concentrates on the reconstruction of the paleotemperatures of the surrounding sedimentary pile and the isotopic compositions, of carbon, oxygen and hydrogen, of source fluids and the temperature range over which the original material was transformed to kaolinite. Temperature

*Address correspondence to this author at the Laboratoire de Géologie, Faculté des Sciences de la Terre, Université Badji- Mokhtar, BP.12, Annaba 23000, Algérie; Tel/Fax: 00.213.38.87.65.62;E-mail: assassi_1@yahoo.fr changes during diagenesis and weathering have been determined using crystallography, oxygen, and hydrogen stableisotope analyses. Reliability of hydrogen isotopes data have been discussed by [5-8]. These authors agree that the hydroxyl group in $10 \AA$ halloysite can exchange $30 \%$ of its hydrogen with interlayer water in minutes, and therefore exchange is fast enough to occur between ambient water and clay during sample preparation in the laboratory. In the absence of data on the exchangeability of collapsed $7 \AA$ halloysite (metahalloysite) and its capacity to re-expand, (h) Hydrogen isotope exchange experiments were undertaken to assess the reliability of $\delta \mathrm{D}$ values of metahalloysite of different grain sizes.

\section{REGIONAL SETTING}

The structural geology of northern Algeria reflects the tectonic changes from Triassic to Miocene times [9]. Our study area is part of the North African Alpine orogeny [4, 10-14] that produced late folding events (Fig. 1). Neritic sequences extended from Trias to Jurassic times and formed over an Algerian -Atlas condensed series of silico-clastic and carbonate materials within pelagic domains. In the Constantine area, Neocomian and Turonian Epochs are exclusively composed of carbonates. This lithology formed by deposition on a platform located towards the southern do- 


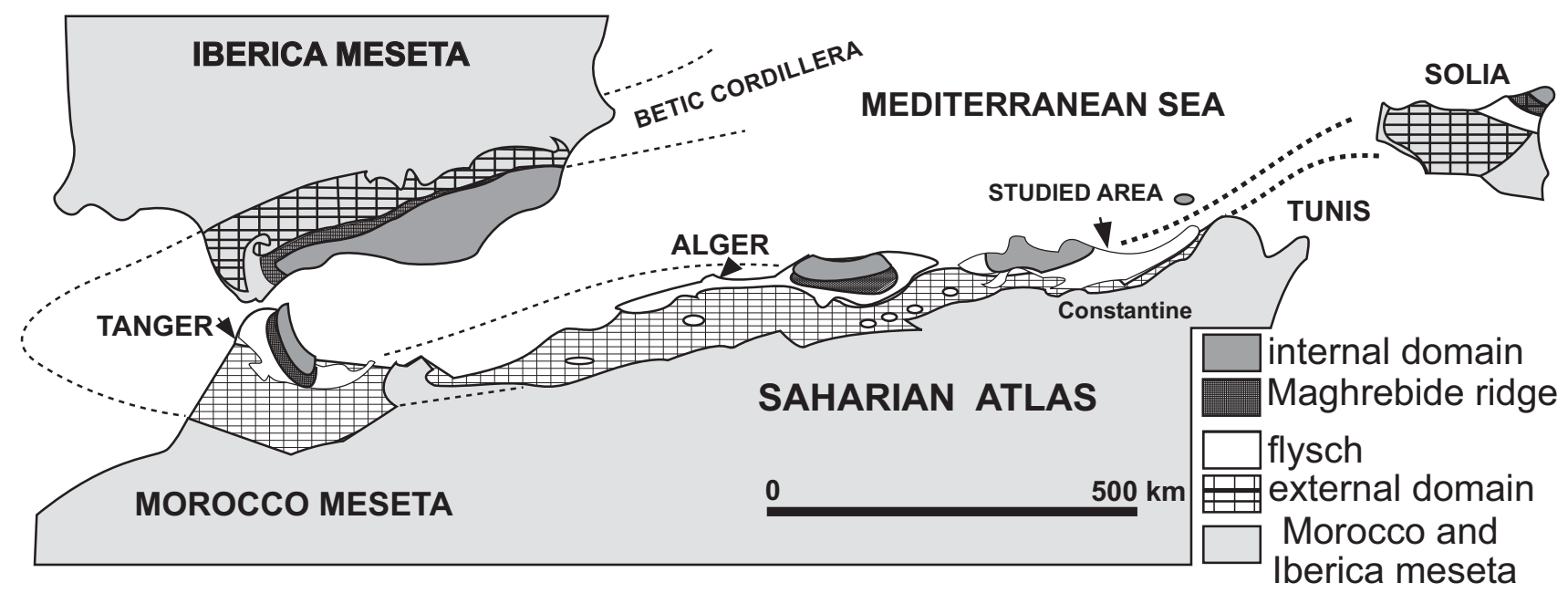

Fig. (1). Map showing the Atlasic-Alpine orogenic with the internal and external domain and major structures from Tunisia to Spain. The Location of the studied area Constantine, Northeast Algeria in rectangle corresponds to the Roknia area shown in Fig. (2) [23]; improved by [14].

main with unconformities over autochthonous and parautochthonous series on its northern part [15] (Fig. 1).

The study area (Fig. 2) contains autochthonous units (Hammam Debbagh) of massive limestones. These limestones include Aptian and Cenomanian units with rare detri- tal quartz, bioclasts such as forams (Aptian stage), rudists and cuneolines (Cenomanian stage) and metre-scale calciteveins. The contact between Cenomanian and the Upper $\mathrm{Nu}$ midian unit is a breccia 'underlying' an unconformity, cut by faults with $\mathrm{E}$ to NW-SE directions. The Numidian unit is mostly composed of argillaceous marls and quartzite's [4,
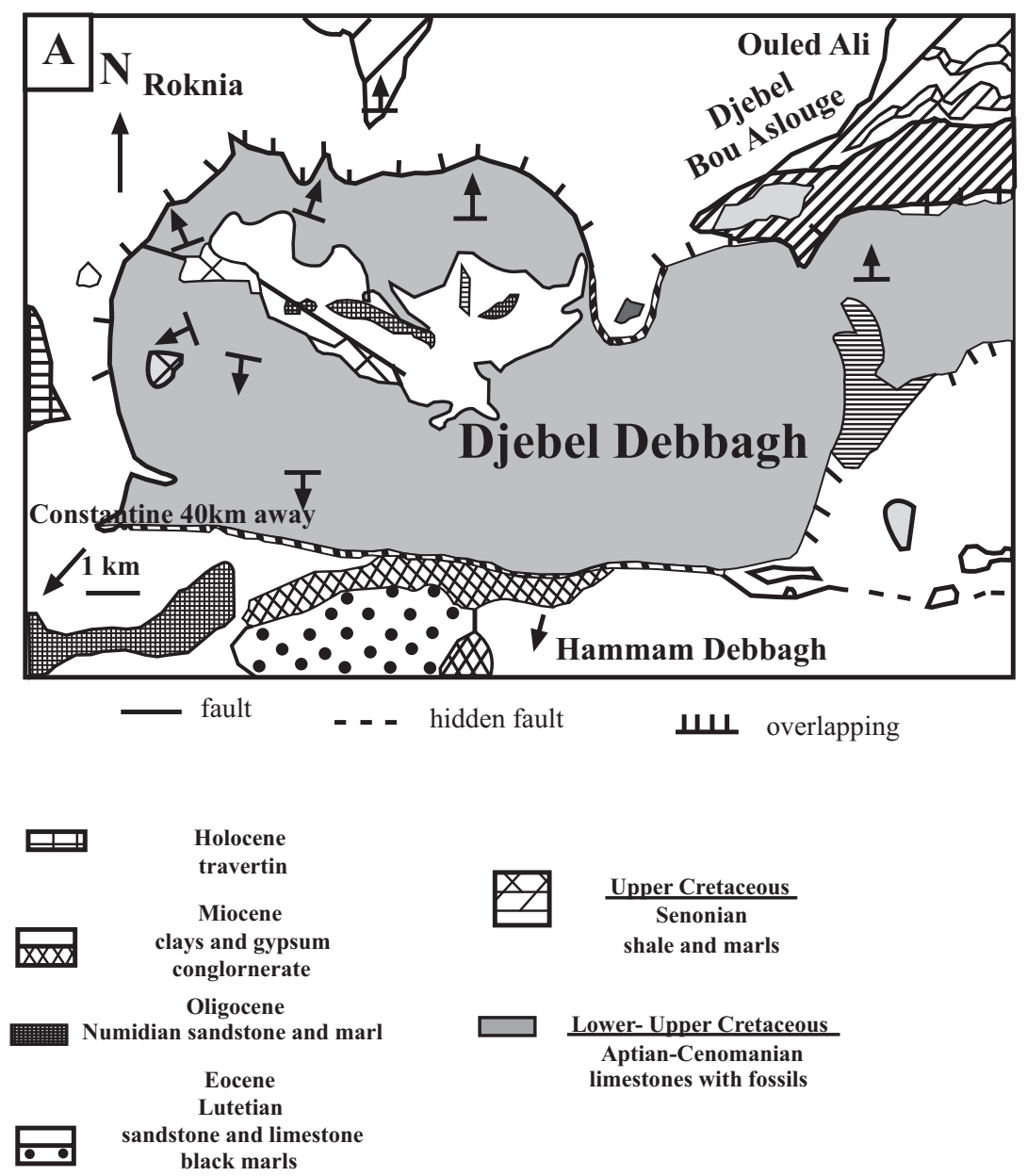

Fig. (2A). General geology and location of kaolin and Arsenium pits for the Djebel Debbagh mining area (omega symbol). Geology includes surrounding sedimentary units (Djebel Bou-Aslouge, Hammam Debbagh), faults at unconformities and anticline direction and slopes. 


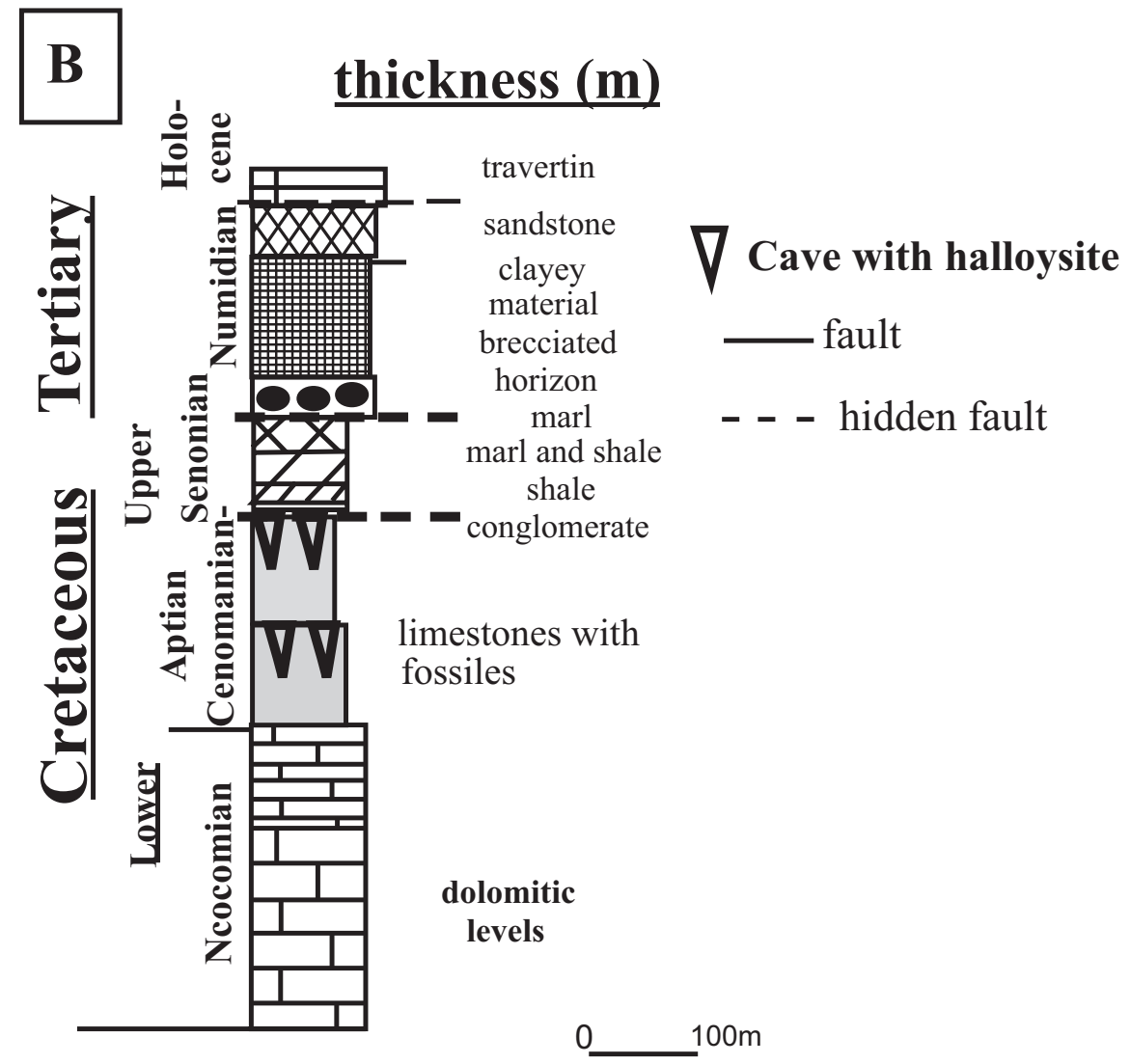

Fig. (2B). Stratigraphic relations along with relative ages between units, lithology and overlapping are also shown [12]; changed by [28], and improved by [4].

16-20]. In Lutetian times, karsts were formed and submerged, producing deposition of clastic sediments $[4,21$, $22]$. In the study area, Eocene-Oligocene strata are absent and allochtonous material and abiologic limestones filled solution cavities in karsts during the Holocene Epoch. The last geological event is related to a neotectonic inverse faulting [26], that eroded and deposited the marl-filling basins to obtain the current geomorphology [3]. Moreover, associated with reverse faulting, several thermal springs (Fig. 2) were activated such as at Ouled Ali $\left(75^{\circ} \mathrm{C}\right)$ and Hamman Debbagh $\left(95^{\circ} \mathrm{C}\right)$.

\section{Karst Location, Geological Setting and Sampling (Fig. 2)}

The Djebel Debbagh mining area is located (Fig. 2), within the Tellian-Atlas Mountains [23]. This mining area extends from NE to NW through Djebel Bou Aslouge and the Roknia depression to the Hammam Debbagh basin [2425], consisting of an Aptian-Cenomanian unit in an anticline area with NW - SE faults [23, 26]. This Aptian-Cenomanian horizon contains 43 karsts filled with clay minerals located in the Lower Aptian unit at a west-east unconformity $\left(125^{\circ}\right.$ North). The Aptian-Cenomanian limestone-units are composed of calcite with less than 1.5 weight $\% \operatorname{MgO}[27,28]$. They are predominantly composed of micritic calcite, and contain rare euhedral quartz and framboidal arsenopyrite (Fig. 4A). A secondary porosity and/or the generation of open fractures can be related to diagenetic and/or neotectonic stages. These karsts have conical shapes on a scale of 2000 to $3000 \mathrm{~m}$ long and 60 to $200 \mathrm{~m}$ deep, and dip roughly from 10 to $20^{\circ}$ to the north. All these "karsts" are overlay by a ferruginous cap-rock containing iron oxide, just as most karsts of the area, and detrital illite, smectite, quartz and lowgrade kaolin ore. This cap-rock formation corresponds to supergene alteration formed between Oligocene and Holocene times [3]. A large proportion of the karsts contain illitic clay-material and kaolin minerals forming a low-grade kaolin ore. These low-grade kaolin ores are composed of mixtures of illite, kaolinite and halloysite associated with minor sulphates such as alunite and jarosite [2]. The focus of this study is on the largest karst in the area ('karst 46', 2000m long and 200m deep, Fig. 3) located at an elevation of 1050 $\mathrm{m}$ above sea level, radially grading from rare breccias at the rim to pure kaolin ore (high-grade) in the centre (Fig. 3). Surrounding the study area, limestones (Aptian unit) with quartz, sulphides in clayey-marls (Senonian unit) contributed particles or chemical constituents to the present-day or chemical components corresponding to the present day filling and mineralogy of karsts [2]. Clayey-marl levels (samples M) are related to Senonian unit located under the karts deposit. These clayey-marls are associated with a metre scale layer of "quartzite" with no overgrowths. Moreover, above the studied karst, a ferruginous cap rock was composed of concretions of goethite, hematite, arsenic-manganese rich oxides, rare fragments of clay material, and detrital quartz (Fig. 4B-C, sample 5 and 19, Table 2). In this karst, pure kaolin ore represent more than $80 \%$ of its volume. The kaolin ore has three different colours and textures (Figs. 3 and 4E-F) that are composed of:

1) High-grade 99 to $90 \%$ of white kaolin (samples 1418), with disseminated large globules of alunite 


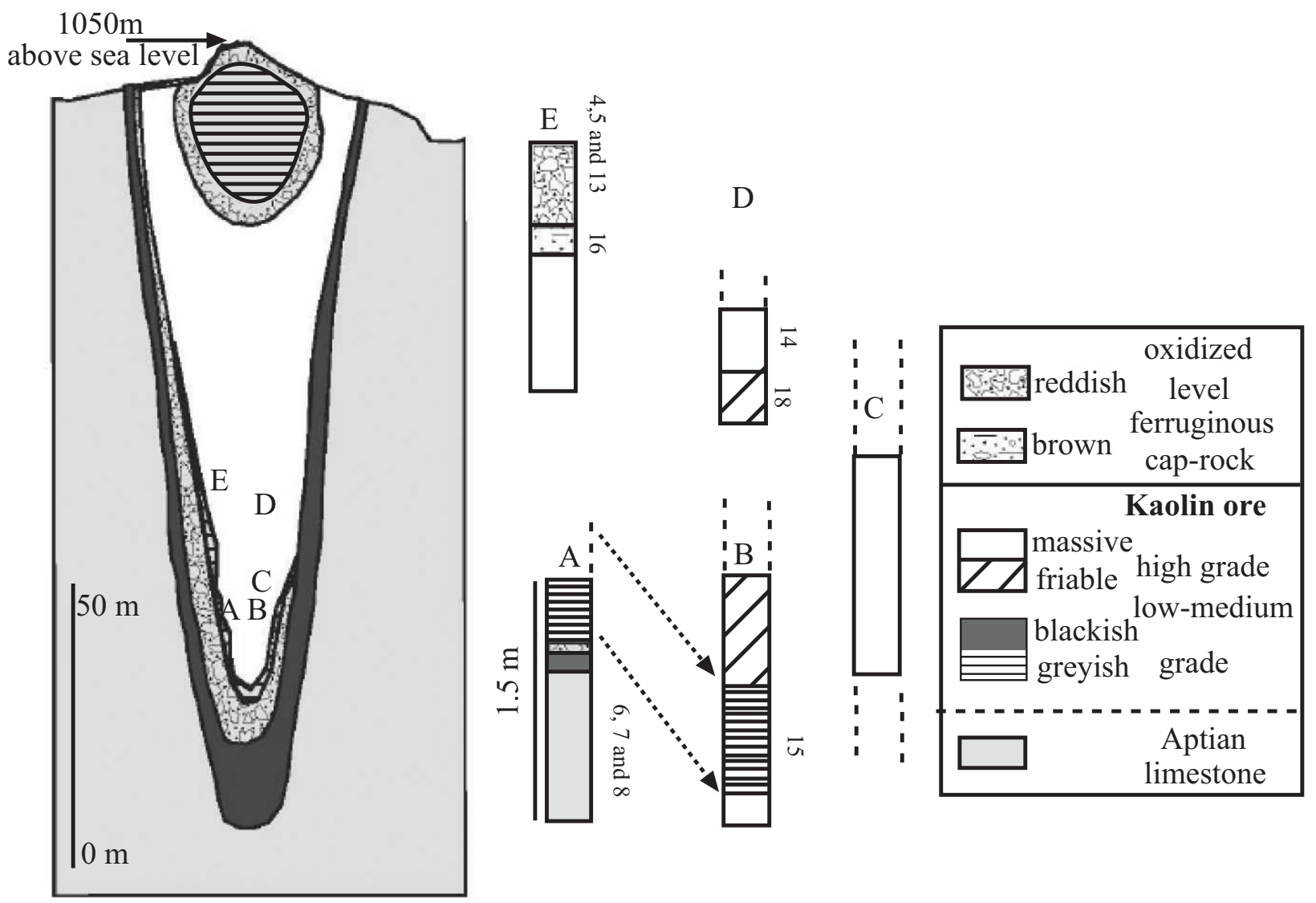

Fig. (3). A schematic cross section of karsts 46 (max altitude of 1050metres above sea level, [27], from the northern Djebel Debbagh area, with the levels sampled location of low (samples 4, 5, 13, 15 and 16), high-grade ore (samples 14, 18), ferruginous cap-rock (sample 9), and Aptian limestones collected within the karst 46 (899 m, Table 1).

$(<3 \%)$ no quartz or chalcedony, and a massive to friable texture.

2) Medium-grade with 80 to $70 \%$ of grey kaolin located at the rims of the karst (Fig. 4D); with very little illite and with 5 to $10 \%$ of iron, minor manganese oxides (sample 16 black) and alunite (sample 15 grey) $[27,28]$.

3) Low-grades correspond to variable compositions with a dominant of iron, manganese oxides such in the cap-rock or the metre scale border between limestones and karst.

\section{ANALYTICAL METHODS}

\section{Petrography, Mineralogy and Chemistry}

Mineralogical identification of carbonates and clays separates were performed on blocks of clays $(\mathrm{kg})$ collected with special care to avoid desiccation. Using optical and electron microscopy (SEM: Jeol 810 with EDS detector) paragenetic sequences have been reconstructed from thin sections and bulk material. Samples $(10 \mathrm{~g})$ were extracted from inside these blocks for clay-size fractions. Clay separates were obtained by settling and centrifuging using distilled water of known stable-isotope composition to constrain and estimate the isotopic changes of the interlayer-water during sample purification. The different size fractions of clays, varying from $<0.5,0.5$ to 1,1 to 2,2 to $5 \mu \mathrm{m}$, bulk materials and their relative proportions were measured by weight. The mineralogy of bulk materials carbonates and clay separates have been analysed using XRD, IR infrared spectroscopy and SEM techniques, to identify minerals and textures. Clay separates and bulk material mineralogy and Full Width at Medium Height (FWMH) of (001) band were determined using XRD with random and oriented sample preparations. Samples were air-dried, glycolated and treated using formamide [HCONH2] $[29,30]$ to re-expand interlayer from 7 to $10 \AA$. XRD patterns were collected using a Brucker D5000 ( $\mathrm{Cu} \mathrm{K} \alpha 1-2 ; 2$ to $65^{\circ} 2 \alpha$ range). Infrared (IR) spectroscopy (Nicolet 510, FTIR), with clay separates, was performed on random pellets. Pellets were made with a ratio of $1 \mathrm{mg}$ sample with $150 \mathrm{mg}$ of $\mathrm{KBr}$ at room temperature and then oven dried at $110^{\circ} \mathrm{C}$ for $24 \mathrm{~h}$. Infrared patterns were collected in an airdried cell, in order to discriminate kaolinite from halloysite and metahalloysite. These petrographical, mineralogical and chemical (H2O weight \%) results are used to determine sample purity prior to stable isotope analyses.

\section{Fluid Inclusions Microthermometry}

Thermometric information such as temperature of entrapment, and salinity, were obtained by microthermometric measurements on $200 \mu \mathrm{m}$ doubly polished thick-sections at less than $70^{\circ} \mathrm{C} \quad[31,32]$. Using a "Chaix-Méca" heating/cooling stage Université Jean Monnet for temperature of 

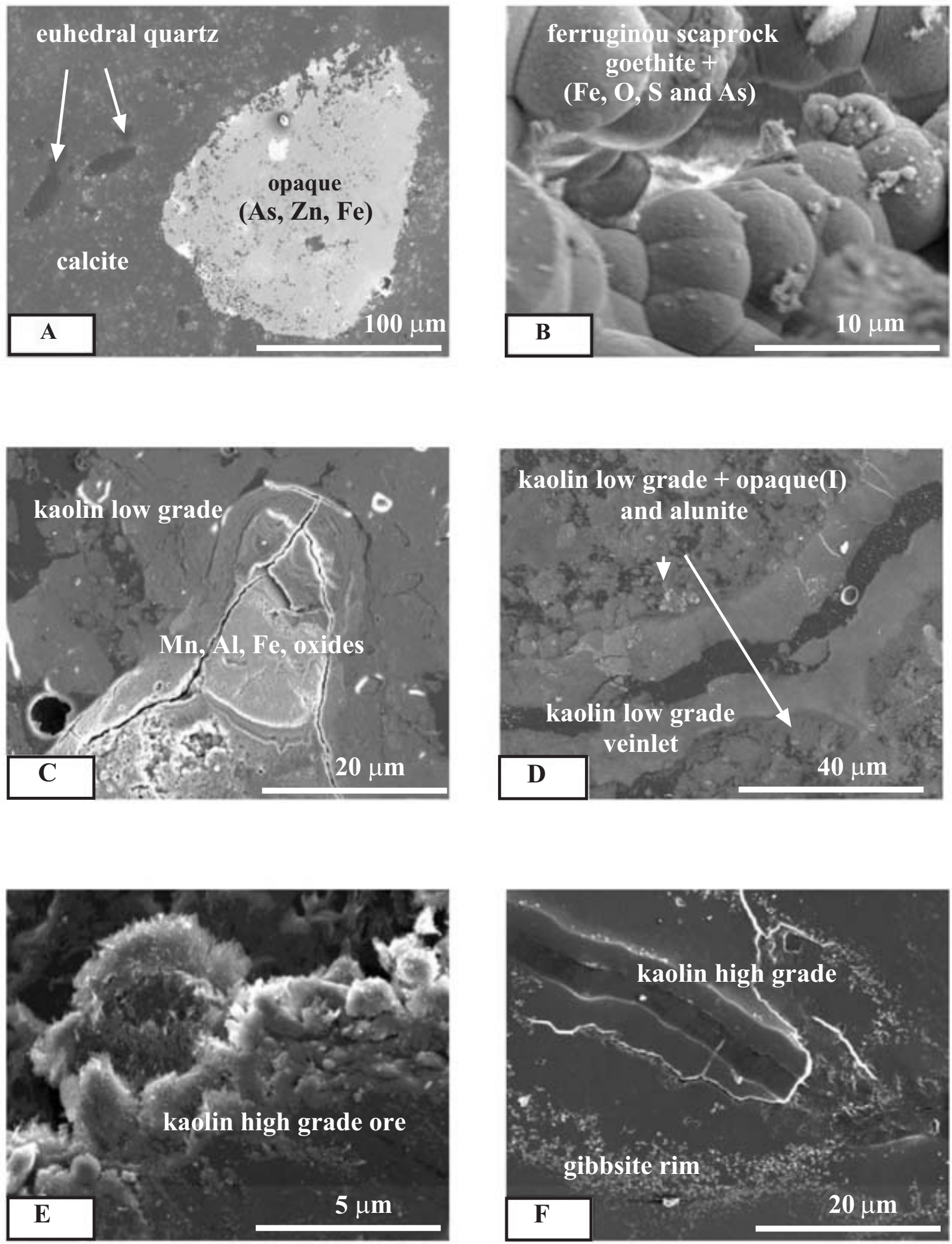

Fig. (4). Microphotographs of thin sections and chips under scanning electron microscope (SEM) of samples presenting aspects of background and karst 46 in the Djebel Debbagh mined ai eà (Fiz. 3). (A) SEM observation of surrounding limestones, showing micritic calcite, disseminated euhedral quartz and a framboidal oxıde (sampıe 2 ). (B) SEM observation of ferruginous concretion within the oxidized cap with iron oxide, sulphur and arsenic minerals (sample 5). (C) SEM photo the ferruginous cap with numerous kaolin precipitation and oolithic structure made of oxides and kaolin material (sample 19). (D) SEM photo of a thin section from the low-grade ore zone with predominant kaolin, disseminated oxides, alunite and organic matter (sample 16). (E) SEM photo of high-grade kaolin ore. (F) SEM photo of high-grade kaolin containing different generations with gibbsite rim (E and F: sample 14) [53]. 
Table 1. Isotopic Compositions $\left(\delta^{13} \mathrm{C} \% \mathrm{~V}-\mathrm{PDB}\right.$ and $\delta{ }^{18} \mathrm{O} \% \mathrm{~V}-\mathrm{SMOW}$ Values) of Calcite from Aptian Unit from Outcrops, within and Surrounding Karst 46 (950m to 895m Above Sea Level) from Djebel Debbagh

\begin{tabular}{|c|c|c|c|c|}
\hline Sample Altitude (m) & $\begin{array}{l}\text { Appearence of Aptian } \\
\text { Limestones }\end{array}$ & Appearance and Mineralogy & $\begin{array}{l}\delta^{13} \mathrm{C} \% \\
\text { V-PBD }\end{array}$ & $\begin{array}{c}\delta^{18} \mathrm{O} \% \\
\text { V-SMOW }\end{array}$ \\
\hline Ca 950m outcrop & $\begin{array}{l}\text { Dominant calci-micrite } \\
\text { with rares } \\
\text { quartz graines }\end{array}$ & $\begin{array}{l}\text { Vein (sparite) } \\
\text { Matrix (micrite) } \\
\text { Matrix (micrite) }\end{array}$ & $\begin{array}{l}1.85 \\
1.52 \\
1.42\end{array}$ & $\begin{array}{l}23.1 \\
24.6 \\
24.2\end{array}$ \\
\hline Ca 949m & $\begin{array}{l}\text { Dominant } \\
\text { calcimicrite }\end{array}$ & $\begin{array}{l}\text { Vein (sparite) } \\
\text { Th-L-V70 to } 110^{\circ} \mathrm{C} \text { (average } 98 \pm 8^{\circ} \mathrm{C}, 15 \\
\text { measurements) Tmice- } 0.9 \text { to }-7^{\circ} \mathrm{C} \text { (average- } 4 \pm 1^{\circ} \mathrm{C} \text { ) } \\
\text { Veinlet (sparite) } \\
\text { Matrix (micrite) }\end{array}$ & $\begin{array}{l}0.82 \\
1.29\end{array}$ & $\begin{array}{l}16.3 \\
21.8 \\
22.4\end{array}$ \\
\hline Ca 948m & Massive sparitic level & $\begin{array}{l}\text { Vein (sparite+oxide)alongstratigraphic } \\
\text { discontinuity } \\
\text { Vein (sparite) } \\
\text { Matrix (micrite) } \\
\text { Matrix (micrite) }\end{array}$ & $\begin{array}{l}0.62 \\
0.86 \\
0.56 \\
0.94\end{array}$ & $\begin{array}{l}21.1 \\
21.6 \\
21.8 \\
22.5\end{array}$ \\
\hline $\begin{array}{l}\text { Ca 900m } \\
\text { Ca karst } 46\end{array}$ & $\begin{array}{l}\text { Dominant calci-micrite and } \\
\text { rares veins }\end{array}$ & $\begin{array}{l}\text { Vein (sparite) } \\
\text { Vein (sparite) } \\
\text { Matrix (micrite) } \\
\text { Matrix (micrite) } \\
\text { Matrix (micrite) }\end{array}$ & $\begin{array}{c}0.61 \\
0.4 \\
-0.04 \\
1.04 \\
1.91\end{array}$ & $\begin{array}{l}22.8 \\
22.6 \\
19.7 \\
22.7 \\
23.8\end{array}$ \\
\hline $\begin{array}{l}\text { Ca 899m } \\
\text { Within the karst }\end{array}$ & Dominant calci-micrite & $\begin{array}{l}\text { Vein (sparite) } \\
\text { Matrix (micrite) } \\
\text { Matrix (micrite) } \\
\text { Matrix (micrite) }\end{array}$ & $\begin{array}{l}0.76 \\
1.73 \\
0.93 \\
1.57\end{array}$ & $\begin{array}{l}21.5 \\
24.2 \\
23.0 \\
24.2\end{array}$ \\
\hline Ca 898m & Dominant calci-micrite & $\begin{array}{l}\text { Matrix (micrite) } \\
\text { Matrix (micrite+oxides) }\end{array}$ & $\begin{array}{l}0.11 \\
0.05\end{array}$ & $\begin{array}{l}18.7 \\
18.4\end{array}$ \\
\hline $\begin{array}{l}\text { Ca 895m } \\
\text { Outcrop }\end{array}$ & $\begin{array}{l}\text { Dominant calcimicrite }+ \\
\text { sparite veins } \\
\text { and quartz grains }\end{array}$ & $\begin{array}{l}\text { Vein (sparite) } \\
\text { Th-L-V70 to } \\
130^{\circ} \mathrm{C} \text { (average } 150 \pm 10^{\circ} \mathrm{C}, 20 \\
\text { measurements) } \\
\text { Tmice- } 1.2 \text { to- }-7.1^{\circ} \mathrm{C} \\
\text { (average- } 2.5 \pm 1^{\circ} \mathrm{C} \text { ) } \\
\text { Matrix (micrite) } \\
\text { Matrix (micrite) } \\
\text { Vein (sparite) } \\
\text { Matrix (micrite) }\end{array}$ & $\begin{array}{c} \\
\\
0.97 \\
0.73 \\
-1.02 \\
0.59\end{array}$ & $\begin{array}{l}23.0 \\
21.9 \\
15.5 \\
21.1\end{array}$ \\
\hline $\begin{array}{l}\text { Close to } \\
895 \mathrm{~m}\end{array}$ & & & & \\
\hline
\end{tabular}

Relative chronology is expressed as matrix of early and late veins of calci-micrite and calci-sparite with fluid inclusion microthermometric data (Th L-V, Tm ice, min, max, averag \pm standard deviation and number of measurements) measured in sparite veins from samples located at $949 \mathrm{~m}$ and $895 \mathrm{~m}$.

homogenisation (Th L-V) of eutectic (Te) and of melting ice (Tm ice) calibration were made using organic compounds with an estimated error of $0.2^{\circ} \mathrm{C}$. Later Tm ices were interpreted as weight $\%$ of $\mathrm{NaCl}$ [33] and density was calculated for pressure correction (Flincor Software) of temperature of homogenisation (Th L-V). Fluid inclusions in micrite calcite are too small to be measured, but microthermometry were observed and measured on crystals from two dm scale calcite vein from levels $895 \mathrm{~m}$ and $949 \mathrm{~m}$ with fluid inclusions located respectively in primary or pseudo-primary settings.

\section{Stable Isotopes}

For isotopic analyses of calcite, $\mathrm{CO} 2$ was liberated from carbonate minerals by reaction with $100 \% \mathrm{H} 3 \mathrm{PO} 4$ at $25^{\circ} \mathrm{C}$ [34]. The extracted CO2 was cryogenically purified. Data were corrected using the carbonate-phosphoric acid frac- 
Table 2. Isotopic Compositions of Hydrogen ( $\delta$ D) and Oxygen $\left(\delta^{18} \mathrm{O}\right)$ Relative to V-SMOW and Weight \% of H2O of Clay-Size Fractions from <0.5, 0.5 to 1,1 to 2 and 2 to $5 \mu \mathrm{m}$, wt \% Correspond to Relative Proportion of Each Size Fraction, with Kaolinite (K), Metahalloysite (mH), Illite Type (I), Smectite (Sm) and Quartz (Q), "' Symbol Correspond to Mixture of Mineral and will not be Discussed

\begin{tabular}{|c|c|c|c|c|c|c|c|}
\hline Samples & Size Fractions $(\mu \mathrm{m})$ & wt $\%$ & Minerals & $\begin{array}{l}\text { (001) Kaolin Minerals } \\
\text { FWHD }^{\circ} 2 \theta \mathrm{Cu}\end{array}$ & $\delta^{18} \mathrm{O} \%$ & $\delta \mathrm{D} \%$ & $\begin{array}{c}\mathrm{H2O} \mathrm{Wt} \\
\%\end{array}$ \\
\hline \multirow{4}{*}{$\begin{array}{c}\text { M } \\
\text { (grey) }\end{array}$} & 0.5 & 23 & $\mathrm{Q}>\mathrm{K}>>\mathrm{Sm}$ & 0.15 & "19.1" & -52 & 6.4 \\
\hline & 1 to 0.5 & 16 & $\mathrm{Q}>>\mathrm{K}>\mathrm{Sm}$ & 0.15 & "21.1" & -55 & 6.0 \\
\hline & 2 to 1 & 26 & $\mathrm{Q}>>\mathrm{K}>\mathrm{Sm}$ & & "20.9" & -56 & 5.0 \\
\hline & 5 to 2 & 36 & $\mathrm{Q} \gg>\mathrm{K}, \mathrm{Sm}$ & & "27" & -54 & 4.5 \\
\hline \multirow{4}{*}{$\begin{array}{c}19 \\
\text { (redish) } \\
\text { friable }\end{array}$} & 0.5 & 12 & K $0.8 ; \mathrm{Sm} 0.2$ & 0.2 & 20.6 & -62 & 11.7 \\
\hline & 1 to 0.5 & 6 & K $0.8 ; \mathrm{Sm} 0.2$ & 0.2 & 19.7 & -61 & 11.6 \\
\hline & 2 to 1 & 12 & Mix with oxides & & "20.7" & "-49" & 13.1 \\
\hline & 5 to 2 & 71 & Mix with oxides & & nd & nd & nd \\
\hline \multirow{4}{*}{$\begin{array}{c}18 \\
\text { (White) } \\
\text { Friable high } \\
\text { grade kaolin }\end{array}$} & 0.5 & 66 & $\mathrm{mH}$ & 0.6 & 19.2 & -48 & 15.5 \\
\hline & 1 to 0.5 & 11 & $\mathrm{mH}$ & 055 & 19.8 & -47 & 14.2 \\
\hline & 2 to 1 & 6 & $\mathrm{mH}$ & 0.5 & 20.3 & -51 & 14.4 \\
\hline & 5 to 2 & 17 & $\mathrm{mH}$ & 05 & 20.7 & -45 & 14.1 \\
\hline \multirow{4}{*}{$\begin{array}{c}18 \\
\text { (black) } \\
\text { Friable low } \\
\text { grade kaolin }\end{array}$} & 0.5 & 2 & $\mathrm{mH}$ & 0.7 & 19 & 41 & 15.7 \\
\hline & 1 to 0.5 & 2 & $\mathrm{mH} 0.9$; alunite $>\mathrm{I}$ & 0.7 & 18.4 & -38 & "8.3" \\
\hline & 2 to 1 & 2 & Mix with oxides & & "20.6" & 45 & 12.0 \\
\hline & 5 to 2 & 94 & Mix with oxides & & "19.5" & 47 & 14.0 \\
\hline \multirow{4}{*}{$\begin{array}{c}15 \\
\text { (grey) } \\
\text { Massive low } \\
\text { grade kaolin }\end{array}$} & 0.5 & 1 & $\mathrm{mH}$ & 0.4 & 19.6 & 48 & 15.7 \\
\hline & 1 to 0.5 & 1 & mH0.9;I 0.1 & 0.4 & 20.1 & 47 & 13.5 \\
\hline & 2 to 1 & 5 & mH0.9; 0.1 & 0.45 & 19.3 & 48 & 14.6 \\
\hline & 5 to 2 & 93 & mixture with alunite & & "20.1" & "-39" & "15.8" \\
\hline \multirow{4}{*}{$\begin{array}{c}14 \\
\text { (white) } \\
\text { Massive high } \\
\text { grade kaolin }\end{array}$} & 0.5 & 4 & $\mathrm{mH}$ & 0.5 & 20.1 & 40 & 15.7 \\
\hline & 1 to 0.5 & 8 & $\mathrm{mH}$ & 0.45 & 19.9 & -37 & 15.5 \\
\hline & 2 to 1 & 21 & $\mathrm{mH}$ & 0.45 & 20.1 & 43 & 14.1 \\
\hline & 5 to 2 & 67 & $\mathrm{mH}$ & 0.45 & 21 & -36 & 14.2 \\
\hline
\end{tabular}

tionation factors of 1.01025 for calcite [35]. Prior to extraction of oxygen, clay minerals $(<5 \mu \mathrm{m})$ were outgassed under vacuum for at least 4 hours at $150^{\circ} \mathrm{C}$ to eliminate adsorbed moisture [5, 36]. Minerals were then reacted with BrF5 $\left(550^{\circ} \mathrm{C}\right)$ to liberate structural and hydroxyl oxygen as $\mathrm{O} 2$ and converted to $\mathrm{CO} 2$ by reaction with a hot carbon rod [36]. Hydrogen for isotopic analysis was extracted from $<5 \mu \mathrm{m}$ clay-size fractions. Samples were dried at room temperature (ambient moisture of $\delta \mathrm{D}$ value of $-195 \% \mathrm{~V}-\mathrm{SMOW}$ ), and then under vacuum in a quartz tube overnight at 150 to $200^{\circ} \mathrm{C}$. Hydroxyl and bonded water were liberated by heating using a butane-oxygen torch and a temperature $c a$. $1300^{\circ} \mathrm{C}$ [38]. The liberated $\mathrm{H} 2 \mathrm{O}$ and $\mathrm{H} 2, \mathrm{H} 2 \mathrm{~S}$ etc... is passed over a $\mathrm{Cu}$ oxide trap at $575^{\circ} \mathrm{C}$, and then converted to $\mathrm{H} 2$ by reduction with uranium at $800^{\circ} \mathrm{C}[2,39]$. The $\mathrm{H} 2$ was trapped in a sample container with activated charcoal at liquid nitrogen temperature.

Isotope analyses of $\mathrm{C}, \mathrm{O}$ and $\mathrm{H}$ were made with $\mathrm{CO} 2$ and $\mathrm{H} 2$ extracted on a dual-inlet GV ISOPRIME mass spec- trometer at Université Jean Monnet. All $\delta^{18} \mathrm{O}$ and $\sigma \mathrm{D}$ values are reported in per mil (\%) relative to the Vienna-Standard Mean Ocean Water (V-SMOW or SMOW, [40-41]. The $\delta^{13} \mathrm{C}$ are expressed as Pee Dee Belemnite (PDB [40, 41]; or VPDB). External error and reproducibility for replicates for $\delta^{13} \mathrm{C}$ are $\pm 0.05 \%$ and $\delta^{18} \mathrm{O} \pm 0.1 \%$ and for carbonates, silicates $\delta^{18} \mathrm{O} \pm 0.3 \%$ and $\delta \mathrm{D} \pm 3 \%$ o $(2 \sigma) ; \delta \mathrm{D} \pm 1 \%$ o $(2 \sigma)$ for water. Data corrected to the V-SMOW and V-PDB scales using international and internal lab standards [43].

\section{Hydrogen Exchange-Experiments}

The two samples selected for the hydrogen isotope exchange experiments are composed of pure metahalloysite (14 and 18) from the high-grade ore. Sample (14) contains a higher proportions of $5-2 \mu \mathrm{m}$ than $<0.5 \mu \mathrm{m}$, whereas sample 18 has dominant $<0.5 \mu \mathrm{m}$ particles (Table 3). These four clays samples (14: $5-2 \mu \mathrm{m}$ and $<0.5 \mu \mathrm{m} ; 18: 5-2 \mu \mathrm{m}$ and $<0.5 \mu \mathrm{m}$ ) ranged in weight from 44.4 to $107.4 \mathrm{mg}$. Each sample was divided into two and placed in separate quartz-glass 
tubes. D/H labelled water at $-62 \%$ was added to one of the tubes and water at $-184 \%$ was added to the other. The tubes were then sealed. The clay was in physical contact with the liquid water. The ratio of water to clay was $15 \mathrm{mg}$ to $1 \mathrm{mg}$, or water to clay hydrogen ratio of $107 / 1$. After 24 months at $23^{\circ} \mathrm{C}$, the sealed tube was opened, water was extracted using a syringe, and the humid clay-separates were freeze-dried under vacuum to eliminate the remaining water, up to visible dryness. Hydrogen isotope values from final water and clayseparates were measured. After the exchange experiments, 99.5 weight \% of water was recovered and the remainder represents adsorbed water on clays. For the clay-size fractions, $\delta \mathrm{D}$ values were obtained using a step-heating extraction method. Hydrogen, principally as water and hydroxyls, was sequential extracted from room temperature up to $800^{\circ} \mathrm{C}$, using $100 \pm 2{ }^{\circ} \mathrm{C}$ steps for 30 minutes followed by a thermal gradient of $20^{\circ} \mathrm{C} / \mathrm{min}$, and then a final higher tem- perature step at $\mathrm{ca} .1300^{\circ} \mathrm{C}$ using an oxygen-butane torch. This procedure was initially set up with two air-dried samples of $<0.5 \mu \mathrm{m}$ size fraction. For each step, total liberated hydrogen was converted to $\mathrm{H} 2$ gas and its yield measured. To compare air-dried "ordinary" clay samples with exchange experiment samples, weight $\%$ of $\mathrm{H} 2 \mathrm{O}$ and weighted $\delta \mathrm{D}$ values were calculated from $200^{\circ} \mathrm{C}$ up to $c a$. $1300^{\circ} \mathrm{C}$ (Table 3).

\section{RESULTS}

\section{Limestones Surrounding Karst 46}

Dominant micritic limestones contain calcite veins and lenses, with multiple directions and dimensions varying from millimetres to metres. The vein calcite crystals analysed for fluid-inclusion microthermometry are doubly zoned and have two phases $\mathrm{H} 2 \mathrm{Oliquid}+$ vapour and $<20 \%$ vapour fluid-

Table 3. Hydrogen-Deuterium Exchange Experiments Between Lab Water of $\delta$ D (*) -66 and (**) -184\%o V-SMOW and Pure Metahalloysites (F18 and F14) from Two Size Fractions of $<0.5$, and 2-5 $\mu \mathrm{m}$ (with their Respective Initial Wt. \% H2O and $\sigma D$ value cf. Table 2) for 2 Years at Room Temperature with Ratio $15 \mathrm{mg}$ Water for $1 \mathrm{mg}$ of Clay

\begin{tabular}{|c|c|c|c|c|c|c|c|c|c|c|c|c|c|c|}
\hline $\begin{array}{l}\text { Sample } \\
(\mu \mathrm{m})\end{array}$ & $\begin{array}{l}\text { Temperature } \\
\left({ }^{\circ} \mathrm{C}\right)\end{array}$ & $\begin{array}{l}\mathrm{Wt} \% \\
\mathrm{H} 2 \mathrm{O}\end{array}$ & $\begin{array}{c}\delta \text { D\%o } \\
\text { V-Smow }\end{array}$ & * & $\begin{array}{l}\mathrm{Wt} \% \\
\mathrm{H} 2 \mathrm{O}\end{array}$ & $\begin{array}{c}\delta \text { D\%o } \\
\text { V-Smow }\end{array}$ & $* *$ & $\begin{array}{l}\text { Sample } \\
(\mu \mathrm{m})\end{array}$ & $\begin{array}{l}\mathrm{Wt} \% \\
\mathrm{H} 2 \mathrm{O}\end{array}$ & $\begin{array}{c}\text { 反 D \%o } \\
\text { V-Smow }\end{array}$ & * & $\begin{array}{l}\text { Wt\% } \\
\text { H2O }\end{array}$ & $\begin{array}{c}\delta \text { D \%o } \\
\text { V-Smow }\end{array}$ & $* *$ \\
\hline $\begin{array}{l}\text { F18 } \\
\text { (5to2) } \\
\text { Wt\% } \\
\text { H2O 14.1 } \\
\delta \text { D\% } \\
-45\end{array}$ & $\begin{array}{l}\text { Ambiant- } 100 \\
100 \text { to } 200 \\
200 \text { to } 300 \\
300 \text { to } 400 \\
400 \text { to } 500 \\
500 \text { to } 600 \\
600 \text { to } 700 \\
700 \text { to } 800 \\
800 \text { to }>1300 \\
\text { (A) ambiant- } \\
\text { ca.1300 } \\
\text { (B) } 200- \\
\text { ca.1300 }\end{array}$ & $\begin{array}{l}0.0 \\
0.45 \\
0.52 \\
1.60 \\
6.13 \\
5.28 \\
0.0 \\
0.25 \\
0.13 \\
\\
\\
\\
\mathbf{1 4 . 3 7} \\
\\
\\
\end{array}$ & $\begin{array}{c}\text { b.d.1 } \\
-59 \\
-62 \\
-46 \\
-35 \\
-37 \\
\text { bdl } \\
-72 \\
-85 \\
-42 \\
\\
\end{array}$ & -66 & $\begin{array}{l}0.1 \\
0.28 \\
0.46 \\
1.61 \\
4.59 \\
5.55 \\
1.88 \\
0.53 \\
0.02 \\
\\
\\
\\
15.02 \\
\\
\\
\end{array}$ & $\begin{array}{c}-54 \\
-44 \\
-51 \\
-53 \\
-37 \\
-40 \\
-39 \\
-54 \\
\text { bdl } \\
\\
\\
-43 \\
\\
\end{array}$ & -175 & $\begin{array}{l}\text { F14 } \\
(5 t 02) \\
\text { Wt } \% \\
\text { H2O } \\
14.2 \\
\delta \text { D\% } \\
-36\end{array}$ & $\begin{array}{l}0.21 \\
0.25 \\
0.2 \\
0.6 \\
1.79 \\
5.74 \\
4.44 \\
2.2 \\
0.01 \\
\\
\\
\\
15.52 \\
\\
\end{array}$ & $\begin{array}{c}-95 \\
-73 \\
-65 \\
-56 \\
-43 \\
-36 \\
-36 \\
-41 \\
\text { bdl } \\
\\
-41 \\
\\
-31\end{array}$ & -66 & \begin{tabular}{|l|}
0.1 \\
0.29 \\
0.37 \\
0.68 \\
2.67 \\
6.77 \\
3.68 \\
0.458 \\
0.24 \\
\\
15.25 \\
\\
\\
\\
$\mathbf{1 4 . 8 6}$
\end{tabular} & $\begin{array}{l}-0.9 \\
-25 \\
-51 \\
-45 \\
-33 \\
-26 \\
-22 \\
-46 \\
-62 \\
\\
-30\end{array}$ & -175 \\
\hline $\begin{array}{l}\text { F18 } \\
(<0.5) \\
W t \% \\
\mathrm{H} 2 \mathrm{O} \\
115.5 \\
\delta \mathrm{D} \% \\
-48\end{array}$ & $\begin{array}{l}\text { Ambiant-100 } \\
100 \text { to } 200 \\
200 \text { to } 300 \\
300 \text { to } 400 \\
400 \text { to } 500 \\
500 \text { to } 600 \\
600 \text { to } 700 \\
700 \text { to } 800 \\
800 \text { to }>1300 \\
\text { (A)ambiant- } \\
\text { ca.1300 } \\
\text { (B) 200-ca.1300 }\end{array}$ & $\begin{array}{l}0.06 \\
0.25 \\
0.45 \\
0.50 \\
1.01 \\
3.78 \\
6.61 \\
1.95 \\
0.78 \\
\\
\\
\\
\\
15.38 \\
\end{array}$ & $\begin{array}{r}-110 \\
-80 \\
-76 \\
-66 \\
-67 \\
-50 \\
-49 \\
-47 \\
-75 \\
\\
\\
\\
-55 \\
-55\end{array}$ & 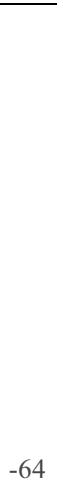 & $\begin{array}{l}0.2 \\
0.24 \\
0.36 \\
1.08 \\
3.32 \\
7.95 \\
1.39 \\
0.41 \\
0.03 \\
\\
\\
\\
\\
\\
\mathbf{1 4 . 9 9} \\
\\
\end{array}$ & $\begin{array}{c}-44 \\
-38 \\
-35 \\
-44 \\
-52 \\
-43 \\
-57 \\
-72 \\
\text { bdl } \\
\\
\\
-47 \\
-48\end{array}$ & -176 & $\begin{array}{l}\text { F14 } \\
(<0.5) \\
\text { Wt\% } \\
\text { H2O } \\
15.7 \\
\delta \mathrm{D} \% \\
-40\end{array}$ & $\begin{array}{l}0.13 \\
0.41 \\
0.45 \\
1.10 \\
7.23 \\
5.77 \\
0.54 \\
0.22 \\
0.03 \\
\\
\\
\\
\\
\mathbf{1 5 . 8 9} \\
\\
\mathbf{1 5 . 3 5}\end{array}$ & $\begin{array}{c}-133 \\
-79 \\
-85 \\
-64 \\
-31 \\
-34 \\
-60 \\
-57 \\
\text { bdl } \\
\\
\\
-41 \\
-40\end{array}$ & & $\begin{array}{l}0.02 \\
0.28 \\
0.35 \\
0.85 \\
4.55 \\
7.49 \\
0.86 \\
0.21 \\
0.06\end{array}$ & $\begin{array}{r}\text { bdl } \\
-67 \\
-79 \\
-67 \\
-38 \\
-33 \\
-49 \\
-71 \\
\text { bdl } \\
\\
\\
-41 \\
-41\end{array}$ & -174 \\
\hline
\end{tabular}

Samples are then freezedried and step heated at a rate of $100^{\circ} \mathrm{C}$ per step, and at 800 up to $c a .1300^{\circ} \mathrm{C}$. For each step from ambient to $c a$. $1300^{\circ} \mathrm{C}, \delta \mathrm{D} \%$ (V-SMOW) were measured, water amounts are normalised to total sample weight and expressed as weight $\%$ of $\mathrm{H}_{2} \mathrm{O}\left(\mathrm{Wt} . \% \mathrm{H} 2 \mathrm{O}\right.$ ). Each step (wt. \% $\left.\mathrm{H}_{2} \mathrm{O}\right)$ were summed to obtain a cumulative Wt. \% $\mathrm{H} 2 \mathrm{O}$ and used to calculate a cumulative $\delta \mathrm{D}$ values from ambient temperature to $c a .1300^{\circ} \mathrm{C}(\mathrm{A})$ and 200 to $c a .1300^{\circ} \mathrm{C}(\mathrm{B})$. 
inclusions. Isolated and doubly zoned fluid inclusions have temperature of eutectic of $-21^{\circ} \mathrm{C}$ with $\mathrm{Tm}$ ices lower than $1.2^{\circ} \mathrm{C}$ (Table 1). Temperatures of homogenisation (Th L-V) of fluid inclusions range from 75 to $130^{\circ} \mathrm{C}$ (average $105^{\circ} \mathrm{C}$, $1 \sigma: 10^{\circ} \mathrm{C}$ ) in a calcite vein located at $895 \mathrm{~m}$ above sea level. Measurements on another vein located at $949 \mathrm{~m}$ above sea level gave a Th $\mathrm{L}-\mathrm{V}$ range from 70 to $110^{\circ} \mathrm{C}$ (average $98^{\circ} \mathrm{C}$, $1 \sigma: 8^{\circ} \mathrm{C}$, Table 1). Stable isotope ratios of carbonates have distinct values and vary between micritic limestones and sparitic veins. Stable-isotope values of whole calcites show a trend of large decreasing ${ }^{18} \mathrm{O}$ associated with a moderate decrease of $\delta^{13} \mathrm{C}$ values (Fig. 5). The micrites have $\delta{ }^{13} \mathrm{C}$ ranging from +2.0 to $-0.5 \%$ and $\delta{ }^{18} \mathrm{O}$ between 18 and $25 \%$. Sparites in veins have slightly lower $\delta{ }^{13} \mathrm{C}$ ranges from +2.0 to $-1.0 \%$ and lower $\delta{ }^{18} \mathrm{O}$ values from 15 to $23 \%$ (Table 1 , Fig. 5).

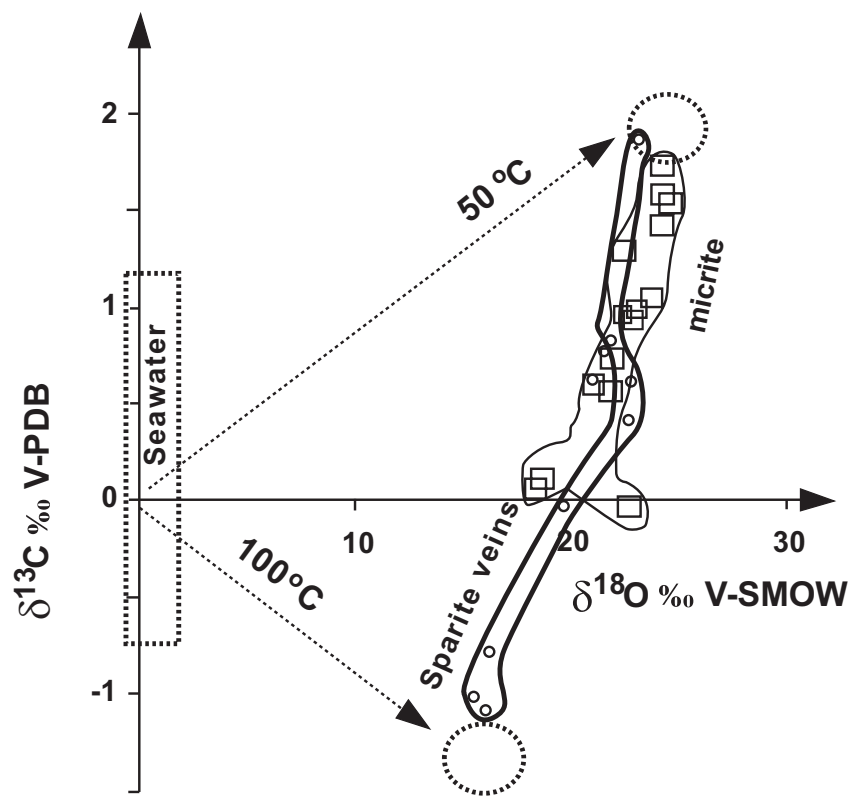

Fig. (5). $\delta{ }^{13} \mathrm{C}$ and $\delta{ }^{18} \mathrm{O}$ values plot of limestones from Aptian unit (grey field) and vein (clear fields) of calcite from the Djebel Debbagh location. Symbols correspond to stable isotopes values from this study (squares $=$ micrite matrix, circles $=$ for calcite veins and veinlets; (Table 1) and shaded square correspond contemporaneous $\delta{ }^{13} \mathrm{C}$ and $\delta{ }^{18} \mathrm{O}$ Tethys seawater estimates located at Tunisia [48]. Dashed fields represents carbonate $\delta^{13} \mathrm{C}$ calcite and $\delta{ }^{18}$ Ocalcite values precipitating in equilibrium with Tethys seawater with $\left(\mathrm{HCO}^{-}=0.001 \mathrm{~mol} / \mathrm{l}\right)$ for temperature of 50 and $100^{\circ} \mathrm{C}[35,47]$.

\section{Clayey-Marls, Ferruginous Cap-Rock and Kaolin Ore From Karst 46}

Most karsts of the area contain low-grade kaolin mixed with illite/smectite and illite sealed by a ferruginous caprock. Above karst 46, the ferruginous cap rock and surrounding clay rich horizon contain clay minerals composed of illite-smectite mixed-layers (R1 type) with less than $30 \%$ of smectite and kaolinite (Table 3). Within the ferruginous caprock, clay minerals mixtures are composed of $80 \%$ of kaolinite and $20 \%$ of illite-smectite. Both clay minerals from ferruginous cap-rock and clayey-marl levels have high crystallinities with full widths at half peak height (001) ranging from 0.3 to $0.1^{\circ} 2 \alpha \mathrm{Cu}$.
SEM observations of low-grade kaolin from the rim of the karst (Fig. 4D; samples 16, 15) show several deformed generations of kaolin (Fig. 4D), whereas oxides and sulphates (15), can form weakly deformed lenses or disseminated globules. Low and high-grade deposits have variable weight $\%$ of clays for similar size fractions with the dominant fraction being larger than $0.5 \mu \mathrm{m}$ (Table 3 ). In the central part of the karst, two samples of pure kaolin (samples 14 and 18) have respectively predominant proportions of $>0.5 \mu \mathrm{m}$ and $<0.5 \mu \mathrm{m}$ particles (Fig. 4E; Table 2). Based on petrographic observations relative chronology between iron, aluminium and manganese oxides, alunite and clays remain unclear.

The XRD patterns of both random and oriented samples from low to medium grade ore show mixtures of dominant kaolin with illite and illite/smectite (samples 16 and 15; Table 2). The high grade kaolin has only (hkl) peaks that could be related to $7 \AA$ (metahalloysite) and/or $1 \mathrm{M} d$ kaolinite, with full widths at half height (001) ranging from 0.7 to $0.4^{\circ} 2 \alpha$ for the different size fractions and none of the formamide treated samples re-expanded the interlayer to $10 \AA$. Infrared absorption patterns of different clay-size fraction from ferruginous cap-rock, and low medium to high-grade kaolin reveal the presence of kaolinite and metahalloysite [41]. In the central part of karst 46, high grade ore composed of metahalloysite (7 $\AA$ ) (Fig. 6) with inner OH-stretching bands at 3695 and $3622 \mathrm{~cm}^{-1}$, and minor outer OHstretching at 3602 and a bump at $3574 \mathrm{~cm}^{-1}$. Whereas Senonian clayey-marl and ferruginous cap-rock show three distinct bands at 3695, 3652 and $3622 \mathrm{~cm}^{-1}$ often related to disordered or ordered kaolinite.

\section{Stable Isotopes Results and Exchange Experiments}

Stable isotope results (Table 2) were measured from pure metahalloysite derived from different size fractions of low to high-grade ore. These metahalloysites have reproducible, but variable, $\delta{ }^{18} \mathrm{O}$ and $\delta \mathrm{D}$ values ranging from 19.0 to $21.0 \%$ and from -36 to $-51 \%$ respectively for each size fraction, with $\mathrm{H} 2 \mathrm{O}$ wt. \% varying from 14.1 to 15.7 (Table 2). These $\delta{ }^{18} \mathrm{O}$ and $\delta \mathrm{D}$ values decrease with decreasing size fraction as $\mathrm{H} 2 \mathrm{O}$ yields increase. Even if metahalloysite did not reexpand during XRD-formamide treatment, $\delta \mathrm{D}$ values and yields might be influenced by exchange with laboratory moisture. Therefore, hydrogen isotope exchange-potential of the samples was examined.

After 24 months, the recovered waters (Table 3) are indistinguishable from the initial water at $-66 \%$ or +8 to $+10 \%$ heavier than $-184 \%$. The metahalloysite gave slightly different results wt. \% H2O, calculated $\delta$ D values from step 200 to $c a .1300^{\circ} \mathrm{C}$ compare to the air-dried metahalloysite total or step heating extracted $\delta$ D values (Table 3 and Fig. 7) $\sigma \mathrm{D}$ values from metahalloysite after the exchange experiments were compared to hydrogen results on air-dried samples. The $\delta \mathrm{D}$ values between air dried samples $\left(150-200^{\circ} \mathrm{C}\right.$ to $\mathrm{ca}$. $1300^{\circ} \mathrm{C}$ ) and exchange experiments steps (200 to ca. $1300^{\circ} \mathrm{C}$, Table 3) have a maximum difference of $-5 \%$ and $\mathrm{H} 2 \mathrm{O}$ varying from -0.2 to $-0.6 \mathrm{wt}$. \%. Patterns of water release are similar from low to high temperature steps for all experiments (Fig. 7a and 7c). Most of the water was extracted between 400 and $700^{\circ} \mathrm{C}$ with a maximum between 400 and $600^{\circ} \mathrm{C}$. However, as mentioned for initial water 


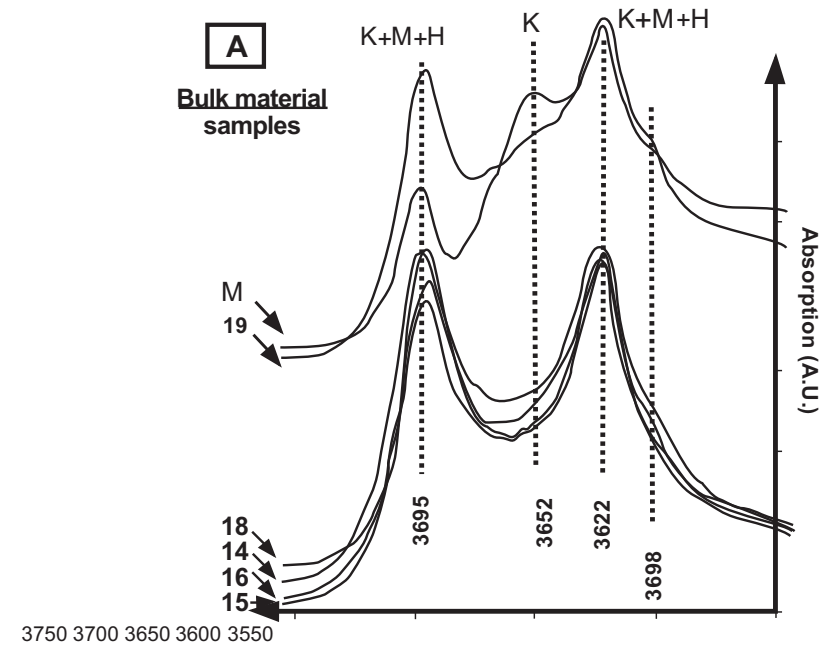

Frequency $\left(\mathrm{cm}^{-1}\right)$

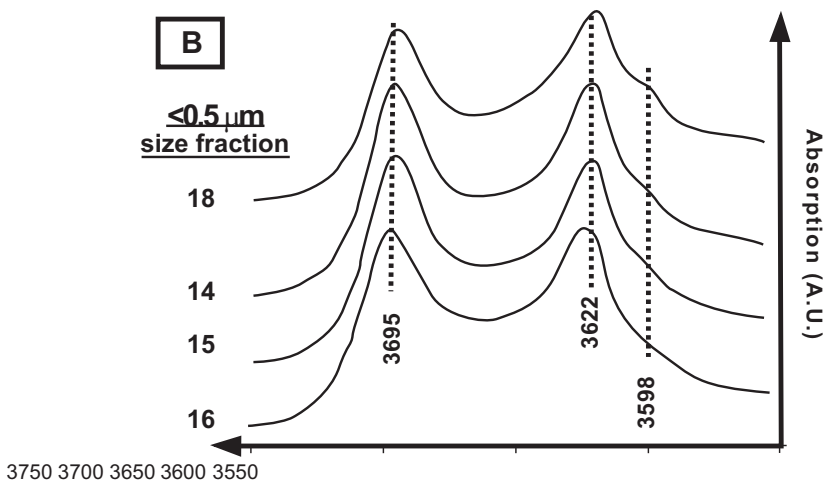

Fig. (6). Infrared absorption patterns from 3550 to $3750 \mathrm{~cm}^{-1}$ carried out on air-dried samples M, 19, 18, 16, 15, and 14 (A: bulk material, B: size fractions lower than $0.5 \mu \mathrm{m}$, samples $18,16,15$ and 14). Major adsorption frequency bands are noted as dash lines with $\mathrm{K}, \mathrm{H}$ and $\mathrm{M}$ standing for characteristic bands of kaolinite, halloysite and metahalloysite [53].

changing from -184 to $-174 \%$, samples of $<0.5 \mu \mathrm{m}$ size fractions have lighter $\delta \mathrm{D}$ values for initial step, from ambient to $100^{\circ} \mathrm{C}$. Initialstep with lower $\delta \mathrm{D}$ values were only noticed for samples reacting with $-66 \%$ initial water and are less negative or does not appear with-184\% exchangedinitial water. Higher heatingsteps gave heavier and variable $\delta$ Dmetahalloysite values. $\delta \mathrm{D}$ values show a progressive "plateau shape" of $\delta$ D between -30 and $-60 \%$ V-SMOW (cumulative weight \% $\mathrm{H} 2 \mathrm{O} v s \delta \mathrm{D}$; Fig. 7b and 7d). From 700 up to $c a \cdot 1300^{\circ} \mathrm{C}$, the amount of $\mathrm{H} 2$ decreased with the lower $\delta \mathrm{D}$ values.

\section{INTERPRETATION}

\section{Diagenesis, Hydrothermal Fluids and Temperature Re- construction}

Facies and pelagic fossils from Aptian to Cenomanian limestone units characterize deposits formed in a confined setting and later on an open platform at the end of Cretaceous time [2]. Petrographic observations of primary micritic-carbonates and silico-clastic materials show secondary porosity, filled with secondary sparitic-calcite as lenses, veins and faults-fractures. These carbonates precipitations were related to peak diagenesis, neotectonism and hydrothermal circulation. Detrital materials retained by most of the karsts in the area consist of kaolinite and illite changed to an illite-smectite interlayer phase (R1) with a ferruginous caprock. Preserved illite-smectite R1 mixed-layered clays suggest that regional temperature would have to be close to $100^{\circ} \mathrm{C}$ [45]. Moreover this ferruginous cap-rock with similar "detrital clays and crystallinities" observed in the surrounding Senonian clay-rich horizons and most karst of the area [1], indicate that the latest weathering fluid was able to transport detrital clay particles to the karsts without transforming the mineralogy. The large volume of high-grade kaolin ore recognized in the Karst 46 compare to neighbour karst suggests that transport permitted just kaolin deposition and/or that weathering processes transformed detrital illite, quartz and increased the grade of the ore. Using temperature of eutectic and $\mathrm{Tm}$ ice of fluid inclusions calculated salinities are $<2$ weight $\% \mathrm{NaCl}$ [33]. These entrapped fluids with low salinities indicate that meteoric fluids circulated in these limestones. Measured temperatures of homogenisation from 70 to $130^{\circ} \mathrm{C}$ do not represent fluid related to deposition of limestones but represent either hydrothermal fluid circulation or diagenetic temperatures in the sedimentary pile. In such case Th $\mathrm{L}-\mathrm{V}$ represent direct temperatures of entrapment during a late Atlasic-Alpine orogeny or reached during compaction and diagenesis of the sedimentary pile. If calcite veins were formed during diagenesis, then Th have to be corrected for diagenetic compaction $\left(30^{\circ} \mathrm{C} / \mathrm{km}\right)$ of $+25^{\circ} \mathrm{C}$ and fluid circulation ranged from 95 to $155^{\circ} \mathrm{C}$. This domain of temperatures is similar to the temperature estimated for smectite to R1 illite-smectite transformation $\left(c a .100^{\circ} \mathrm{C}\right)$. Carbon and oxygen isotope data from micritic and sparitic calcites can be interpreted in a number of ways, both in terms of processes responsible for observed variability as well as in terms of the source itself. $\delta{ }^{13} \mathrm{C}$ data from carbonates are dependent upon temperature, Eh and $\mathrm{pH}$ during precipitation and carbon-bearing species in solution [46]. Considering petrographic observations with nearby mineral assemblages of iron and manganese oxides or sulphates, chemical and isotopicschanges are related to oxidizing conditions. Therefore, $\delta \quad \mathrm{C}$ values of carbonates indicate that were controlled by temperature and $\mathbb{1 3 O} 2-\mathrm{H} 2 \mathrm{O}$. Then $\delta \quad \mathrm{C}$ carbonates values are equivalent to $\delta \mathrm{CHCO}^{-}$or $\delta^{13} \mathrm{CCO} 2$ and $\delta$ Cfluid. Therefore, stable isotopes data of calcites were used to estimate the source of carbon, and oxygen for temperature estimates [35, 47], and/or to define fluid changes related to surrounding carbonate series associated with diagenesis, fluid migration and interaction. An interpretation would be to assume that that primary micritic calcite in matrix were in equilibrium with Albo-Aptian, Tethys seawater $\left(\delta^{18} \mathrm{O}\right.$ fluid close to $0 \% \mathrm{~V}$ - SMOW; [48] (Fig. 5). Therefore calculated temperature of equilibriums are related to compaction with a range of temperatures from 45 to $88^{\circ} \mathrm{C}$ (Table 1) and some veins at temperatures similar to fluid inclusion results $\left(54\right.$ to $\left.116^{\circ} \mathrm{C}\right)$. Using each calculated temperatures, $\delta^{13} \mathrm{CHCO}^{-}$values in equilibrium range from 0.5 to $3.7 \%$ V-PDB with slightly more negative values for veins (Table 1). This interpretation considering a unique $\delta^{18} \mathrm{O}$ fluid of sea water indicate that calculated $\delta^{13} \mathrm{CHCO}^{-}$values are higher than commonly observed for atmospheric $\mathrm{CO} 2$ in 


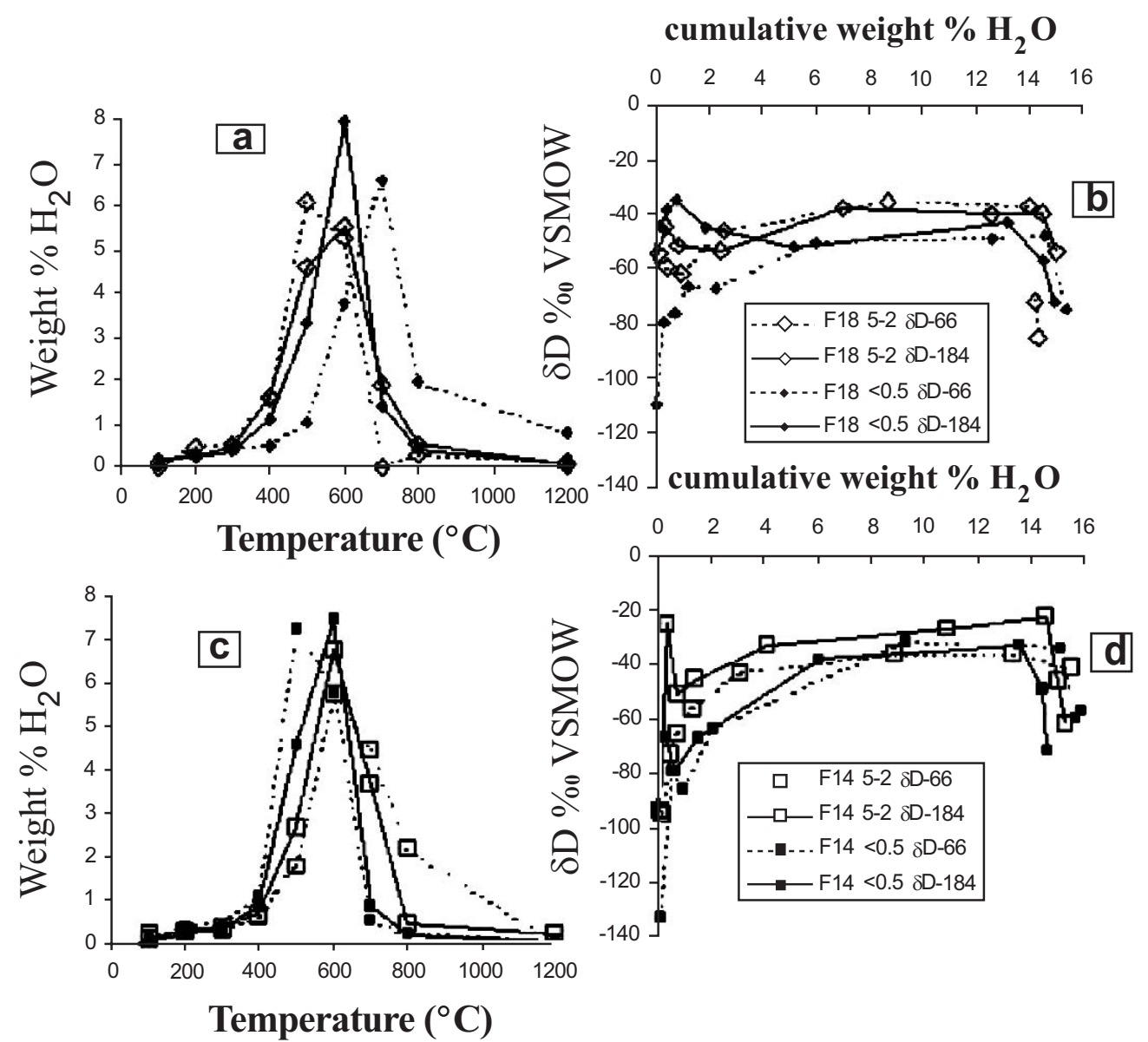

Fig. (7). "Hydrogen-isotope exchange experiments between two different starting waters ( $\delta$ D of -66 and $-184 \%$ ) and pure-metahalloysite samples 14 (a and b) and 18 (c and d) with different size-fractions. a) and c) are weight $\% \mathrm{H} 2 \mathrm{O}$ extracted versus temperature $\left({ }^{\circ} \mathrm{C}\right)$, and $\mathrm{b}$ and $\mathrm{d}$ are cumulative weight $\% \mathrm{H} 2 \mathrm{O}$ versus individual-step $\delta \mathrm{D}$ values $\left(\%\right.$, V-SMOW) with increasing temperature from ambient to $c a$. $1300^{\circ} \mathrm{C}$ [53].

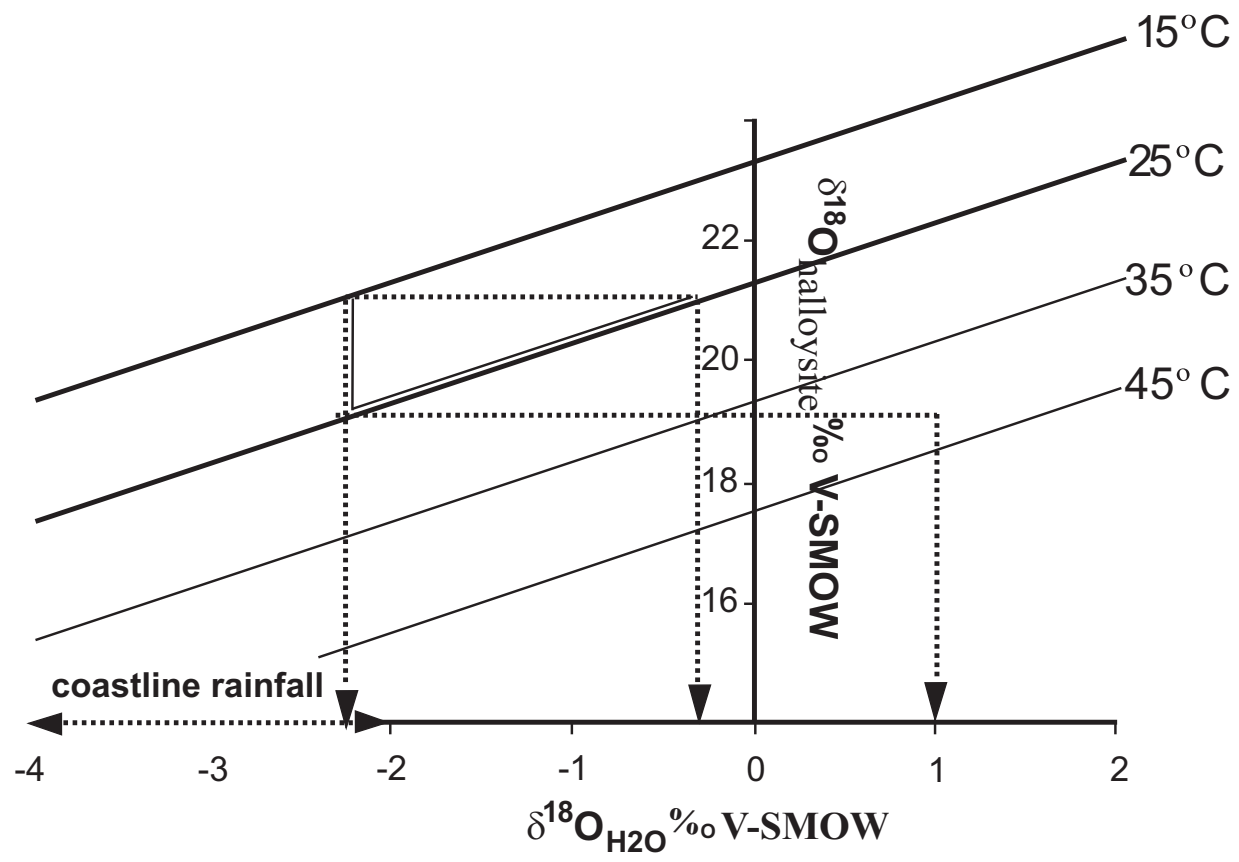

Fig. (8). Diagram showing $\delta{ }^{18}$ Ohalloysite $v s \delta{ }^{18} \mathrm{OH} 2 \mathrm{O}$ values at different temperatures of equilibration from 15 to $45^{\circ} \mathrm{C}$ from present-day $\delta$ ${ }^{18} \mathrm{OH} 2 \mathrm{O}$ values [51] ranging from -2 to $-4 \%$ and past seawater [48]. $\delta^{18} \mathrm{O}$ values and 19.3 to $21.1 \%$ of metahalloysite from $\mathrm{Dj}$. Debbagh (dashed domain, karst 46) as well as possible interpretations. a) open (several influx of water) or close system (initial fluid and fractional crystallisation, see text) b) decreasing temperature with similar water, along crystallisation from big to small particle size of metahalloysite. 


\section{$\delta^{18} \mathrm{O} \%$ V-SMOW}

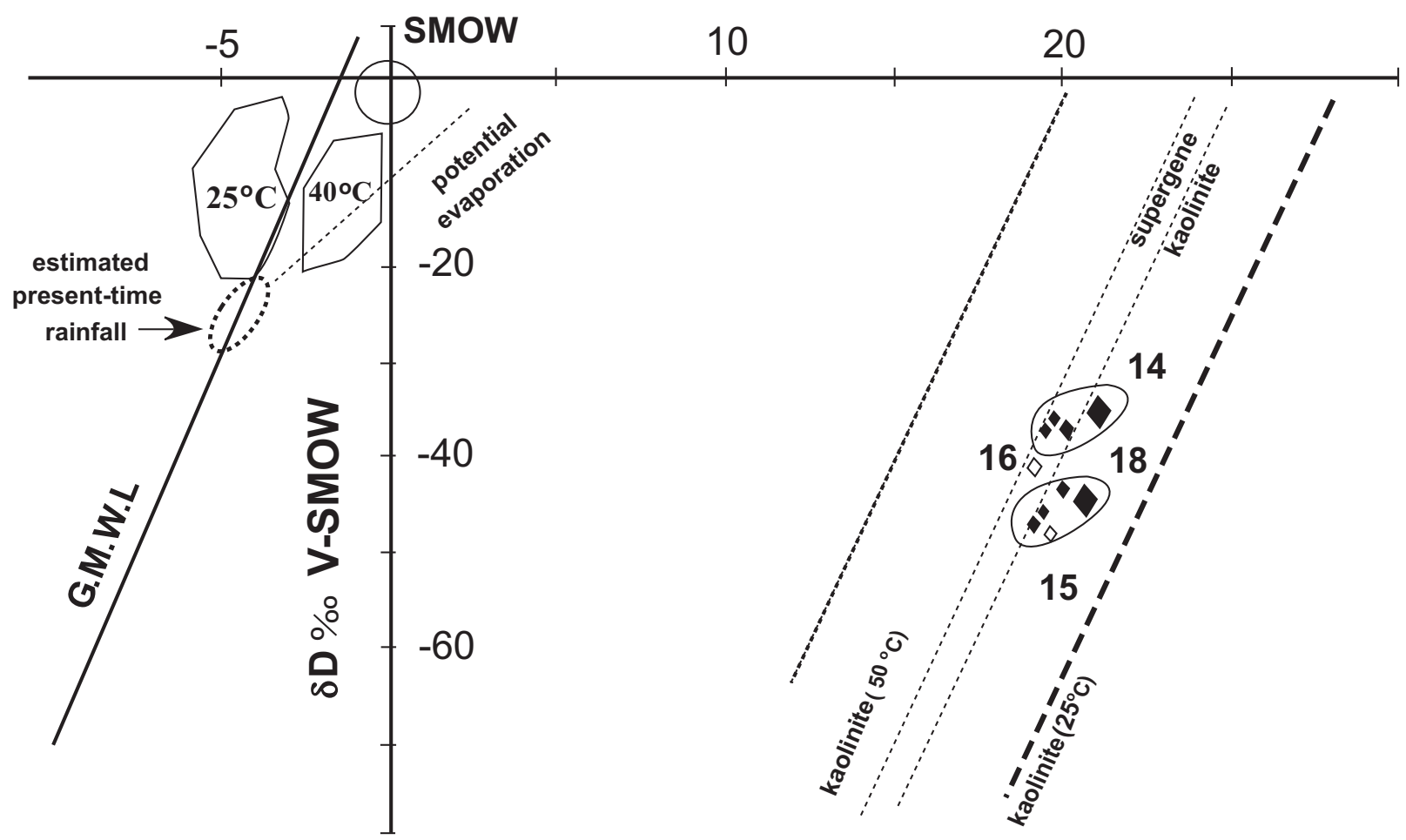

Fig. (9). Diagram showing $\delta{ }^{18} \mathrm{O} v s \delta \mathrm{D}$ (air-dried samples) of pure metahalloysite (clear diamonds: low grade, 15 and 16; field diamond: high-grade, 14 and 18 ) with kaolinite-water equilibration-line $\left(25\right.$ and $\left.50^{\circ} \mathrm{C}\right)$. On the global meteoric water line $(\mathrm{G} . \mathrm{M} . \mathrm{W} . \mathrm{L}),. \delta^{18} \mathrm{OH} 2 \mathrm{O}$ and $\delta \mathrm{DH} 2 \mathrm{O}$ of estimated present-time rainfalls and SMOW domain are plotted as well as $\delta{ }^{18} \mathrm{O}$ and $\delta \mathrm{D}$ values of water in equilibrium with metahalloysite for 25 and $40^{\circ} \mathrm{C}$ and a potential evaporation-line (cf. Table 5).

equilibrium with seawater [47]. Moreover, this hypothesis would deny the influence of fluid associated with Alpine deformation.

An alternative interpretation would be to simultaneously interpreted carbon and oxygen isotopes data in equilibrium with fluids with temperatures of fluid inclusions ranging from 70 to $130^{\circ} \mathrm{C}$ (Table 4).

-Micrite (matrix calcite) had $\delta{ }^{13} \mathrm{CHCO} 3$ and $\delta{ }^{18} \mathrm{OH} 2 \mathrm{O}$ fluid values varying respectively from 1.7 to $3.7 \% 0,-2.3$ to $+3.9 \%$ \% $\left(70^{\circ} \mathrm{C}\right)$ and -1.5 to $3.4 \% \mathrm{~V}-\mathrm{PDB}$ and 4.2 to $10.2 \% \mathrm{~V}$ SMOW $\left(130^{\circ} \mathrm{C}\right)$. This temperature of $130^{\circ} \mathrm{C}$ gives too positives $\delta{ }^{13} \mathrm{C}$ and $\delta{ }^{18} \mathrm{O}$ values to represent a fluid-circulation related to evaporation or even the diagenesis of a sedimentary pile. Calculated $\delta{ }^{13} \mathrm{CHCO} 3$ and $\delta{ }^{18} \mathrm{OH} 2 \mathrm{O}$ in equilibrium with $70^{\circ} \mathrm{C}$ correspond to coastline-seawater evolving with diagenesis.

-Sparite veins, just as micrite (matrix calcite), would had too positive calculated $\delta^{18} \mathrm{O}$ fluid with a temperature of $130^{\circ} \mathrm{C}(\delta$ ${ }^{13} \mathrm{CHCO} 3-: 1.5$ to $3.3 \%$ V-PDB and $\delta{ }^{18} \mathrm{OH} 2 \mathrm{O}:+5.5$ - to $+8.9 \%$ V-SMOW) and suggest that most calcite veins and veinlets emplacement were related to lower temperature probably be associated with matrix compaction.

-At the exception of the calcite veins located at 895 and $949 \mathrm{~m}$, with fluid inclusions and Th L-V fluid of $130^{\circ} \mathrm{C}$ (Table 1) and fluid in equilibrium with $\delta{ }^{13} \mathrm{CHCO} 3$ and $\delta{ }^{18} \mathrm{O}$ values ranging from 0.5 to $0.7 \%$ and 1.3 to $2.1 \%$ respectively. These fluid values might correspond to hydrothermal fluids with recharge of bicarbonate interacting with atmospheric $\mathrm{CO} 2$ or freshwater (Fig. 5).

\section{Karst 46}

In the karts 46, petrographical, mineralogical and size differences between rim and centre of the karst indicate that low and high-grade ore recorded multiple stages of weathering fluids due to emplacement or weathering processes. As well as the other karsts, "karst 46" must have had contained large amounts of detrital clay minerals derived from clayrich beds such as the Senonian unit [2]. Based on petrographic observations and XRD results, many clay-size fractions of low grade ore are mixtures of different clay minerals and cannot be use for temperature or fluid reconstructions. The large amount of metahalloysite in karst 46 indicates reworking of the cave with high grade ore that indicate a special "plumbing" system compare to other karst.

Considering exchange experiments, the high water/rock ratio, the change of $\delta \mathrm{D}$ value for the lightest initial water indicate that some hydrogen isotope have exchanged in contact with metahalloysite. Some metahalloysite samples have lighter $\delta \mathrm{D}$ values for initial step from ambient to $100^{\circ} \mathrm{C}$, which agree with exchange between water and metahalloysite. However, this initial step does not appear in each experiment because of the small amount of water collected from ambient to $100^{\circ} \mathrm{C}$ but also suggest that exchanges between water and mineral occurs with absorbed water removed during freeze drying at room temperature. At higher steps, the water and hydroxyls were extracted between 400 and $700^{\circ} \mathrm{C}$ with a maximum in agreement with the literature and TGA under He or N2 atmosphere [49]. Hydrogen extraction of step-heated samples indicate that light water was not 
Table 4. Present-Time Altitude of Samples with Appearance Described as Vein (Sparite) and Matrix (Micrite): (a) Temperature of Equilibration $\left({ }^{\circ} \mathrm{C}\right)$ Corresponding to the Paleotemperature of Formation of Micrite and Sparite Using $\delta{ }^{18}$ Ocalcite and Tethys Sea Water [48] with a $\delta{ }^{18} \mathrm{OH} 2 \mathrm{O}$ Value of $0 \%$ V-SMOW Using Oxygen Fractionation-Factor from [22]. (b) Simultaneously, Using these Temperatures $\delta{ }^{13} \mathrm{CHCO3}^{-}$in Equilibrium with Calcite were Calculated with Carbon Fractionation-Factors [47]. $\delta^{13} \mathrm{CHCO3}^{-}$and ${ }^{18} \mathrm{OH} 2 \mathrm{O}$ were Also Calculated Using Minimum $\left(70^{\circ} \mathrm{C} ; \mathrm{c}\right)$ and $\mathrm{Maximum}\left(130^{\circ} \mathrm{C} ; \mathrm{d}\right)$ Temperatures Measured in Fluid Inclusions

\begin{tabular}{|c|c|c|c|c|c|c|c|}
\hline $\begin{array}{l}\text { Sample } \\
\text { Altitude }\end{array}$ & $\begin{array}{l}\text { Appearance } \\
\text { Mineralogy }\end{array}$ & $\begin{array}{c}\mathrm{T}\left({ }^{\circ} \mathrm{C}\right) \text { f or } \\
\delta^{18} \mathrm{OH} 20: 0 \% \text { (a) }\end{array}$ & $\begin{array}{c}\delta^{13} \mathrm{CHCO3 \%} \\
\text { V-PBD (b) }\end{array}$ & $\begin{array}{c}\delta^{13} \mathrm{CHCO3 \%} \\
\text { V-PBD }\left(70^{\circ} \mathrm{C}: \mathrm{c}\right)\end{array}$ & $\begin{array}{l}\delta^{18} \mathrm{OH} 2 \mathrm{O} \% \\
\text { V-SMOW:c }\end{array}$ & $\begin{array}{c}\delta^{13} \mathrm{CHCO3 \%} \\
\text { V-PBD }\left(130^{\circ} \mathrm{C}: \mathrm{d}\right.\end{array}$ & $\begin{array}{l}\delta^{18} \mathrm{OH} 2 \mathrm{O} \% \\
\text { V-SMOW:d }\end{array}$ \\
\hline \multirow{3}{*}{$\begin{array}{l}\text { Ca 950m } \\
\text { outcrop }\end{array}$} & Vein (sparite) & 54 & 3.6 & 3.6 & 2.4 & 3.3 & 8.9 \\
\hline & Matrix (micrite) & 45 & 3.4 & 3.2 & 3.0 & 3.0 & 10.4 \\
\hline & Matrix (micrite) & 47 & 3.2 & 3.7 & 3.5 & 2.9 & 10.0 \\
\hline \multirow[t]{2}{*}{ Ca 949m } & $\begin{array}{c}\text { Vein (sparite) } \\
\text { (fluid inclusion) }\end{array}$ & 108 & 0.8 & 0.9 & -4.4 & 0.7 & 2.1 \\
\hline & Matrix (micrite) & 58 & 3.1 & 3.0 & 1.7 & 2.8 & 9.2 \\
\hline \multirow[t]{3}{*}{ Ca 948m } & $\begin{array}{c}\text { Vein } \\
\text { (sparite+oxides }\end{array}$ & 67 & 2.3 & 2.3 & 0.4 & 2.1 & 6.9 \\
\hline & Vein (sparite) & 64 & 2.6 & 2.6 & 0.9 & 2.3 & 7.4 \\
\hline & Matrix (micrite) & 62 & 2.3 & 2.3 & 1.1 & 2.0 & 7.6 \\
\hline \multirow{3}{*}{$\begin{array}{c}\text { Ca } 900 \mathrm{~m} \\
\text { Ca karst } \\
46\end{array}$} & Matrix (micrite) & 78 & 1.6 & 1.7 & -1.0 & 1.4 & 5.5 \\
\hline & Matrix (micrite) & 57 & 2.8 & 2.8 & 2.0 & 2.5 & 8.5 \\
\hline & Matrix (micrite) & 50 & 3.7 & 3.6 & 3.1 & 3.4 & 9.6 \\
\hline \multirow{4}{*}{$\begin{array}{c}\text { Ca 899m } \\
\text { Within the } \\
\text { karst }\end{array}$} & Vein (sparite) & 58 & 2.5 & 2.5 & 0.8 & 2.2 & 7.3 \\
\hline & Matrix (micrite) & 47 & 3.6 & 3.4 & 3.5 & 3.2 & 10.0 \\
\hline & Matrix (micrite) & 55 & 2.7 & 2.6 & 2.3 & 2.4 & 8.8 \\
\hline & Matrix (micrite) & 47 & 3.4 & 3.3 & 3.5 & 3.1 & 10.0 \\
\hline Ca 898m & $\begin{array}{c}\text { Matrix } \\
\text { (micrite)Matrix } \\
\text { (micrite+oxide) }\end{array}$ & $\begin{array}{l}86 \\
88\end{array}$ & $\begin{array}{l}1.8 \\
1.7\end{array}$ & $\begin{array}{l}1.8 \\
1.8\end{array}$ & $\begin{array}{l}-2.0 \\
-2.3\end{array}$ & $\begin{array}{l}1.6 \\
1.5\end{array}$ & $\begin{array}{l}4.5 \\
4.2\end{array}$ \\
\hline
\end{tabular}

recovered in steps above $200^{\circ} \mathrm{C}$, with no relation between size fractions and initial $\delta \mathrm{D}$ steps. Therefore, these metahalloysites have a low exchangeable capacity. Moreover, airdried and cumulative weight $\% \mathrm{H} 2 \mathrm{O}$ from exchange experiments have up to $2 \%$ higher theoretical yields than halloysite (12 wt. \% H2O) and close to kaolinite, with no relation to any specific step. To obtain this theoretical weight $\%$ of $\mathrm{H} 2 \mathrm{O}$ of halloysite or metahalloysite an unrealistic dehydration of $400^{\circ} \mathrm{C}$ would have to be applied. These results especially with $-184 \%$ V SMOW labelled water do not agree with the exchange experiments realised by $[5,50]$, which show $35 \%$ of exchange on halloysite at $25^{\circ} \mathrm{C}$ and predicted expandablehalloysite $\delta$ Dhalloysite value of $-110 \%$ V-SMOW after a few minutes. Our results emphasize that exchange of hydrogen did not occur during sample collection or laboratory preparations. These interpretations would indicate that $\mathrm{OH}$ - stretching vibrations of metahalloysite, bonded-hydroxyl groups and Al-O-Si groups are ordered enough to prevent isotopic exchange of hydrogen during 24 months and $23^{\circ} \mathrm{C}$. Therefore, $\delta \mathrm{D}$ values of metahalloysite are considered meaningful and related to metahalloysite ordering. However in the case of $\delta \mathrm{D}$ values represent a progressive transformation of halloysite to ordered metahalloysite; samples can still have suffered an initial exchange. Therefore, $\delta \mathrm{D}$ values would have to be considered as an average "signature" integrating time and temperature processes during dehydration and hydroxyl ordering.

\section{Temperature Estimations Using Present-Day Climatic Condition}

Several interpretations can be drawn using oxygen stable isotope data for paleotemperature or fluid reconstruction. If 
Table 5. Temperature $\left({ }^{\circ} \mathrm{C}\right)$ of Equilibrium of Pure Metahalloysite Samples from Low and Highgrade Ore Calculated Using Estimated Rainfall $\left(\delta^{18} \mathrm{OH2O}:-5.5 \%\right.$ V-SMOW and Halloysite Fractionation Equation; [38]. Calculation of the $\delta{ }^{18} \mathrm{OH} 2 \mathrm{O}$ of Water in Equilibrium with Metahalloysite Sample Using Halloysite-H2O Oxygen Fractionation-Factor $\left(25^{\circ} \mathrm{C}\right)$. Calculations of the $\delta{ }^{18} O$ and $\delta D$ of Water in Equilibrium with Metahalloysite Using Kaolinite-H2O Oxygen and Hydrogen Fractionation Factors for 25 and $40^{\circ} \mathrm{C}\left(\delta^{18} \mathrm{OH} 2 \mathrm{O}\right.$ and $\left.\delta \mathrm{DH} 2 \mathrm{O}\right)$

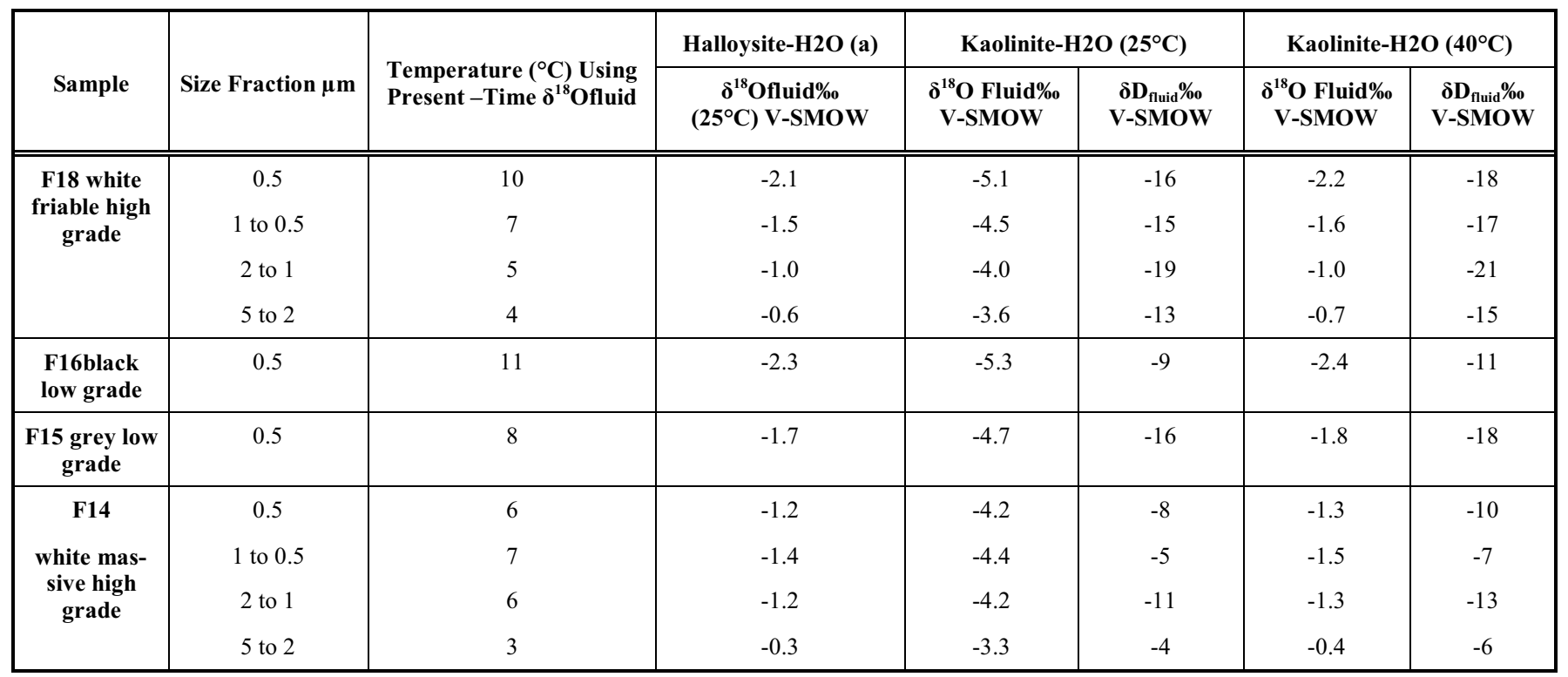

continental weathering produced the formation and transport of detrital clays into the karsts, then present-day rainfall might have influenced oxygen and hydrogen stable isotopes values of initial $\mathrm{Si}-\mathrm{Al}$ gels or halloysite.

If $\delta \mathrm{D}$ values correspond to an integrated event, then present-day oxygen exchange must be discussed. Therefore a present-day coastline meteoric water [51] and ${ }^{18} \mathrm{O}$ altitudinal gradient of $-0.15 \% / 100 \mathrm{~m}$ [52], then rainfalls are close to a $\delta$ ${ }^{18} \mathrm{O}$ value of $-5.5 \% \mathrm{~V}-\mathrm{SMOW}$, and present-day altitude and slope do not allow large evaporation. Moreover, thermal springs have $\delta{ }^{18} \mathrm{OH} 20$ value $c a$. $-8 \% \mathrm{~V}$-SMOW. Therefore, $\delta{ }^{18} \mathrm{O}$ value of $-5.5 \%$ was considered for potential exchange processes between halloysite and rainfall during Holocene to present-day times. Calculations indicate temperatures of equilibrium between 3 and $11^{\circ} \mathrm{C}$ (Table 5) that would correspond to paleosoil temperature [53]. However these temperatures do not explain why all karts with a ferruginous cap rock are not filled by metahalloysite and rules out oxygen exchange at present day conditions.

\section{$\delta^{18}$ O Fluid Using Past Climatic Conditions}

Considering that metahalloysite precipitated during Miocene to Holocene Epochs, then its temperature of formation is constrained considering average minimum and maximum temperatures [54] estimated temperatures between $15^{\circ} \mathrm{C}$ and $25^{\circ} \mathrm{C}$. Such a temperature range allows a calculation of $\delta$ ${ }^{18}$ Ofluid in equilibrium to be made using kaolinite and/or halloysite $-\mathrm{H} 2 \mathrm{O}$ oxygen fractionation factors $[8,55]$ (Table 5, Fig. 8). Considering a system mineral -water at equilibrium conditions at $25^{\circ} \mathrm{C}$, then smaller size fractions of pure metahalloysite were in equilibrium with $\delta{ }^{18}$ Owater between -2.1 and $-1.4 \%$ V-SMOW, whereas larger size fractions were close to $\delta{ }^{18}$ Owater $-0.6 \%$ V-SMOW (Fig. 8a). Such $\delta^{18} \mathrm{OH} 2 \mathrm{O}$ values change may indicate that large and small clay particles equilibrate with fractional-crystallisation proc- ess or $\delta{ }^{18} \mathrm{OH} 2 \mathrm{O}$ was changing with time. For a constant value of ${ }^{18} \mathrm{OH} 2 \mathrm{O}$ arbitrary fixed at $-2.3 \% \mathrm{~V}-\mathrm{SMOW}$, the temperature increased from 15 to $25^{\circ} \mathrm{C}$ at the time that the small particles were forming (Fig. 8b). Such scenario are more likely than the earlier interpretation [2] but all interpretations requires rainfall at lower altitude and the karst to be located at the coastline. However, these calculations do not explain why all karsts are not only filled by metahalloysite ore. A possible reason would be that water/rock ratio were higher in the studied karst than in the others

\section{Temperature Estimations Using Hydrogen and Oxygen Stable Isotopes Data}

As previously mentioned the $\delta \mathrm{D}$ values might correspond to superimposed events such as precipitationdehydration and crystal-structure ordering. From exchange experiments and assumptions of $\delta \mathrm{D}$ value representing metahalloysite formation, temperatures can be estimated using oxygen and hydrogen stable isotope values (Fig. 9). The $\delta \mathrm{D} v s \quad \delta^{18} \mathrm{O}$ diagram indicates (Fig. 9; Table 5) that metahalloysite is in equilibrium with temperatures between 40 and $25^{\circ} \mathrm{C}$, with stable isotope values of fluids in equilibrium with $\delta{ }^{18} \mathrm{O}$ fluid -0.4 to $-2.4 \%$ and $\delta$ Dfluid -4 to $21 \% \mathrm{~V}$-SMOW. These estimated temperatures are higher than supergene alteration by rainfall precipitated in a coastline setting. This range of temperatures from 40 to $c a .25^{\circ} \mathrm{C}$ for metahalloysite indicates surficial $[8,55]$ to evaporitic conditions of metahalloysite precipitation. These temperatures confirm that metahalloysite formed from fluid and temperature lower than "Alpine-hydrothermalism" or present-day thermal springs $\left(>75^{\circ} \mathrm{C}\right)$, as previously mentioned as responsible of metahalloysite precipitation [1]. However, the high-grade volume of metahalloysite compare to other karsts has to be related to preferential fluid circuit not associated with neotectonics. 


\section{CONCLUSIONS}

Supported by geomorphological, paleontological and sedimentological studies, Chinese reports (anonymous), [3, 4] emphasized an infilling of karsts and shallow weathering of surrounding limestones, marl and sandy-clay rich marls, during Lutetian and Miocene times. They consider "Cretaceous" and especially Senonian Formations [2] as a source of kaolin and detrital material. The latest study by [1] suggested hydrothermal alteration at higher temperatures related to hypothetical leaching out of major elements as seen in the thermal springs of the area.

Stable isotopes results presented in this paper from carbonates and silicates reveals several fluid-temperature histories. Surrounding limestones from the Aptian to Cenomanian units were first precipitated in seawater then at a temperature of 50 to $70^{\circ} \mathrm{C}$ during diagenesis, followed by a maximum temperature of $130^{\circ} \mathrm{C}$ associated with neotectonic, and consisting of mixture of saline fluid from seawater with rainfall. During Miocene-Holocene Epochs, ore composed of metahalloysite was formed or transformed in karsts from detrital clays. In the studied karst, high-grade metahalloysite ore content minor gibbsite, alunite and quartz absent indicate that water compositions were acidic sulphate with low $\mathrm{Si}$ content. These element coming from exposed and oxidized pyrite and/or silicate-rich Senonian units. Such acidic solution containing $\mathrm{Si}$ and $\mathrm{Al}$ could have been buffered by surrounding carbonates, while precipitating disseminated sulphates and Si-Al gels or alteration and replacement of detritus of clays, forming halloysite-metahalloysite [56-60]. The temperature of clay precipitation can be estimated using oxygen and hydrogen stable-isotope data. Considering metahalloysite formation with paleogeographic, paleotemperature conditions at Miocene to Lutetian time, $\delta \mathrm{D}$ and $\delta{ }^{18} \mathrm{O}$ temperatures ranges indicate surficial kaolinite $[8,55]$ to evaporitic conditions. The temperature is lower than that predicted for hydrothermal fluids measured in the carbonates or thermal springs, and previously considered as responsible of metahalloysite precipitation [53]. Considering paleoclimate changes at Lutetian to Miocene times from 15 to $25^{\circ} \mathrm{C}$, several interpretations are possible. Exchange experiments between metahalloysite-H2O during 24 months $\left(23^{\circ} \mathrm{C}\right)$ attest that metahalloysite does not allow hydrogen exchange in laboratory conditions. Therefore, $\delta \mathrm{D}$ values are reliable; increases with smaller size fraction and the difference between metahalloysite and kaolinite are either related to temperature variation from 15 to $25^{\circ} \mathrm{C}$ or exchanges. However, considering paleoclimate and geographic conditions, and assuming $25^{\circ} \mathrm{C}$ temperature of equilibrium, $\delta{ }^{18} \mathrm{O}$ and $\delta \mathrm{D}$ values of fluid are similar to $\delta{ }^{18} \mathrm{O}$ and $\delta \mathrm{D}$ of rainfall in coastline settings with slight evaporation [53].

\section{AKNOWLEDGMENTS}

I wish to thanks Mines of Guelma and especially ENOF office of Debbagh to permit sampling and provide field supports and information for this study. Annaba University for travel expenses. Pr; J-Y Cottin for invitations to work in University Jean Monnet and technical staff for analyses. Centre Spin of Saint Etienne Mining School and Hydrasa in University of Poitiers for XRD, SEM and infrared accesses. Many thanks to Peter Bowden for their knowledge and encouragement.

\section{REFERENCES}

[1] M. Bourezg, "mineralogical and geochemical study of hat iron in the north-east Algerian" Magister Thesis, University of Constantine, Algeria, pp. 130, jun 1989

[2] A. Talbi, " karstic mineralization study of DJebel Debbagh occidental (Guelma), " Magister Thesis, University Houari Boumédiene, Algiers, Algeria, pp. 157, Sept 1987.

[3] A. Toubal, "Contribution study of mineralization antimonifères of northeastern of Algeria: hétérochrome province", Doctoral Thesis, University of Paris VI, pp. 141, Jun 1984.

[4] J. M. Vila, " The Alpine chain of western of Algeria and Confins Algerian-Tunisian", Thesis of Sc. Nat. University of Pierre and Marie Curie, Paris, pp. 665, 40 figures, Jun 1980.

[5] J. C. C. Hsieh, C. J. Yapp, " Hydrogen isotope exchange in halloysite: insight from room temperature experiments" Clays.Clay Miner., vol. 47, pp. 811-816, 1999.

[6] J. R. Lawrence, "O18/O16 and D/H ratios of soil, weathering zones and clay deposits" Thesis for the Doctor of Philosophy, California institute of technology Pasadena, California. pp. 272, 1970.

[7] J. R. Lawrence, Jr. H. P. Taylor, "Deuterium and oxygen-18 correlation: clay minerals and hydroxides in Quaternary soils compared to meteoric water". Geochim. Cosmochim. Acta, vol. 35, pp. 9931003, 1971.

[8] S. M. F. Sheppard, H. A. Gilg, "Stable isotope geochemistry of clay minerals", Clay Miner., vol 31, pp. 1-24, 1996.

[9] Wildi, "The chain Tello -Rifaine (Algeria, Morocco, Tunisia) Stratigraphic structure and evolution of the Triassic Miocene", thesis, University of Paris, pp. 300, Jun 1983.

[10] J. Blayac, " geological esquisse of the seybouse basin and some neighbouring areas, "Bull. Serv. Map Geol., Algeria, vol. 2, No. 6. Algiers, 1912.

[11] J. Dareste de la Chavanne, "Guelma region. Special study of tertiairy deposits", PhD Thesis. University of lyon, Publ. Serv. Géol. Carte., Algeria, vol., pp. 50, 20fig, 5 pl. 1910.

[12] P. Deleau, " Detailled Geological Map of Meskoutine Hammam, " Sheet No. 53. 1/50.000 to. Ed Serv. Geol., Algeria, 1937.

[13] P. Deleau, "Geological study of Jammaps - Hammam Meskoutine regions and of $\mathrm{Col}$ of oliviers, "Bull. Serv. Map. Geol., Algeria. 2nd: Stratigraphy - Regionales Descriptions, vol. 14, Volume 2, 1938.

[14] J. M. Vila, "The méridionaux témoins of the môle Néritic Constantinois south of Hammam Meskoutine and Guelma (Algéria)". Bull. Soc. Hist. Nat. Afr. Nord., vol. 63, fasc.1-2, 4 fig., Algiers, pp.2937, 1977.

[15] J. M. Vila, "The Constantine Rocks: Stratigraphy, microfauns and structural position, " Bull. Soc. Hist. Nat. Afr., North, vol. 65, fasc1-2, 1 fig, 7pl, Algiers, pp. 385-392, 1974.

[16] J-P. Bouillin, J. F. Raoult, "The olistostrome Presence in the socle kabyle of constantinois a Linked to load the flyschs; Numidien may be a neo-indigenous? "Bull. Soc. Géol. Fr., vol.7 XIII, 338-362, 8 fig. Paris, 1971.

[17] J. P. Bouillin, "Geology alpine of the small Kabylie of Collo and El Milia region (Algeria), "PhD Thesis University of Paris, pp. 509, 127 fig, 1 map, Paris, Sept 1977.

[18] J. P. Gelard, "Geology of the North-East of the Great Kabylie (the internal segment of orogène North African coast)." Thesis. University of Dijon, pp. 326, 98fig, 19pl, 1 map h.t. color. Jun 1979.

[19] J. F. Raoult, E. Fourcade, "Cretaceous of Kef Hahouner and stratigraphic position" veolina oval. Recheli " (series northern of mole neritic Constantinois. Algeria), " micropal Rev., Vol 15 No. 4. Paris, pp. 227-246, 1973.

[20] J. F. Raoult, "Paleogeographic and structural Evolution of the Alpine chain between the Gulf of Skikda and Constantine (Algeria Eastern):, pre-print. Department of Structural Geology, Univ. Paris IV, pp. 22, 1974

[21] J. C. Lahondére, J. Magne, "The evolution of the field in the neritic Constantinois of Guelma region at the end of Secondary and early Tertiary, palaeogeographic consequences "CR. Acad. Sc. Paris, vol. 297 , pp. $775-776,1983$.

[22] J. C. Lahondére, "The ultra-telliennes series of North-East of Algeria and the surrounding formations in their structural framework." PhD Thesis. University Paul Sabatier Toulouse pp. 238, Sept 1987.

[23] M. Durand-Delga, "Mise au point of the structure of the NE of Berberie" Bull. Serv. Map. Geol., Algeria (new series), vol. 39, pp.89-131, 1969. 
[24] J. M. Vila, J. Magne, "The structural framework of the DJebel Debbagh (North Constantinois. Algeria)" Bull. Soc. Geol. Fr., vol.7, T. XI, pp.75-81, 1969.

[25] J. M. Vila, "Recurrence of the window of autochtonus HahounerDebar (sheet to 1/50.000 Gounod-La Mahouna, north-east of Constantinois (Algeria)." Bull. Soc. Géol. fr., vol. 7, T. XII, 3fig. Paris, pp. 813-817, 1970.

[26] J. M. Vila, Explanatory note of the geological map at 1/200.000. Sheet Constantine. Serv. Carte. Géol. Algeria / Sonatrach, 1977.

[27] Sonarem. Reports (anonymous), Internal report of the Chinese mission on the Kaolin of DJebel Debbagh, 1965-1967

[28] Sonarem. Reports (anonymous), Internal report of the Sovietic mission on the Kaolin of Djebel Debbagh, 1978- 1981.

[29] E. Brouard, "Study of cryptokarsts girders Forest Bessède (Perigord, France), and between the Meuse and Sambre (Belgium): lithology, geochemistry, and néogenèse evolution of karst systems, " Doctoral thesis in Sciences from the University of Paris-South Orsay (France) and the Polytechnic Faculty of Mons, Belgium, pp. 270, 1992.

[30] G. J. Churchman, J. S. Whitton, G. G. C. Claridge, B. K. G. Theng, "Intercalation method using formamide for differentiating halloysite from kaolinite". Clays Clay Miner., Vol. 32, n4, pp.241-248, 1984.

[31] E. Roedder, Fluid inclusions. Rev. in Mineralogy., vol. 12, pp. 644, 1984.

[32] T. J. Shepherd, A. H. Rankin, D. H. Alderton, A practical guide for fluid inclusion studies, Blackie.

[33] Y. G. Zhang, J. D. Frantz, "Determination of the homogenisation temperatures and densities of supercritical fluids in the system $\mathrm{NaCl}-\mathrm{KCl}-\mathrm{CaCl} 2-\mathrm{H} 2 \mathrm{O}$ using synthetic fluid inclusions", Chem. Geol., vol. 64, pp.335-350, 1987.

[34] J. M. McCrea, "On the isotopic geochemistry of carbonates and a paleotemperature scale", J. Chem. Phys., vol. 18, pp.849-857, Jun 1950.

[35] I. Friedman, J. R. O'Neil, "Compilation of stable isotope fractionation factors of geochemical interest". USGS Prof. Paper 440-KK, 1977.

[36] K. Ziegler, J-C. C. Hsieh, O. A. Chadwick, E. F. Kelly, D. M. Hendricks, S. M. Savin, "Halloysite as a kinetically controlled end product of arid-zone basalt weathering", Chem. Geol., vol. 202, pp.461- 478, Feb 2003.

[37] R. N. Clayton, T. D. Mayeda, "The use of bromine pentafluoride in the extraction of oxygen from oxides and silicates for analysis", Geochim. Cosmochim. Acta, vol. 27, pp. 43-52, 1963.

[38] J. D. Goldfrey, "The deuterium content of hydrous minerals from the East-Central Sierra Nevada and Yosemite National Park", Geochim. Cosmochim. Acta, vol.26, pp.1215-1245, 1962

[39] J. Bigeleisen, L. Perlman, M. H. C. Prosser, "Conversion of hydrogenic materials to hydrogen for isotopic analysis", Anal. Chem., vol. 24, pp. 1356-1357, 1952.

[40] R. E. Criss, H. P. Jr Taylor, "Stable isotopes in High temperature Geological processes, Meteoric-hydrothermal systems", Chap. 11 (J. W. Valley, H. P. Taylor Jr. and J. R. O’Neil Editors.), vol.16, Rev. Mineral., pp.373-424, 1986.

[41] Jr. H. P. Taylor, S. Epstein, "Relation between oxygen isotope ratios in coexisting minerals of igneous and metamorphic rocks: I. Principles and experimental results", Bull. GSA, vol. 73, pp. 461480, 1962

[42] H. Craig,." Isotopic standards for carbon and oxygen and correction factors for massspectrometricanalysis of carbon dioxide", Geochim. Cosmochim. Acta, vol. 12, pp. 133-149, 1957.
[43] T. B. Coplen, "Normalization orf oxygen and hydrogen isotopes data", Chem. Geol (Isotope geoscience section), vol. 72, pp. 293297, 1988

[44] H. H. Murray, "Kaolin Minerals: Their genesis and occurences", Rev. Mineral., vol. 19, pp.68-87, 1989

[45] B. Lanson, B. Velde, "Decomposition of X-ray diffraction patterns: A convenient way to describe complex I/S diagenetic evolution", Clays Clay Miner., vol. 40, pp.629-643, 1992.

[46] H. Ohmoto, R. O. Rye, "Isotope of sulfur and carbon, in Barnes", H. L. Ed., Geochemistry of Hydrothermal deposits, John Wiley \& Sons, pp. 509-567, 1979.

[47] W. G. Mook, J. C. Bommerson, W. H. Staverman, Carbon isotope fractionation between dissolved bicarbonate and gaseous carbon dioxide. Earth. Planet. Sci. Lett., vol. 22, pp.169-176, 1974.

[48] I. Jarvis, A. Mabrouk, R. T. J. Moody, S. de Cabrera, "Late Cretaceous (Campanian) carbon isotope events, sea-level change and correlation of the Tethyan and Boreal realms", Palaeogeography, Palaeoclimatology, Palaeoecology, vol. 188, pp. 215-248, Sept 2002.

[49] E. Eslinger, M. Peaver, 1988. SEPM Short Course Notes, vol. 22, pp. 343.

[50] R. Fagan, F. J. Longstaffe, " Hydrogen-isotope exchange in smectite ? "Program with abstracts, International Clay Conference, Ottawa, p. A97, June 15-21, 1997.

[51] H. Celle-Janton, K. Zouabri, Y. Travi, A. Daoud." Caractérisation isotopique des pluies en Tunisie. Essai de typologie dans la région de Sfax", C. R. Acad, Serie II, t 333, vol. 10, pp.625-631, 2001

[52] L. Araguas, K. Froehlich, K. Rozanski, "Deuterium and oxygen-18 isotope composition of precipitation and atmospheric moisture, " Hydrol. Process, vol. 1 03, pp.230-244, 2000.

[53] F. Assassi, " Reconstruction of fluids temperatures of karstic mineralisation of kaolin of westhern of Djebel Debbagh (Guelma, Northeasthern of Algeria), PhD Thesis, University Badji-Mokhtar, Annaba, Algeria. pp.161, Dec 2006

[54] J. Zachos, M. Pagani, L. Sloan, E. Thomas, K. Billups, "Trends, rythms, and aberrations in global climate $65 \mathrm{Ma}$ to present". Science, vol.292, pp.686-693, 2001.

[55] H. A. Gilg, S. M. F. Sheppard, " Hydrogen isotope fractionation between kaolinite and water revisited", Geochim. Cosmochim. Acta, vol. 60, pp.529-533, 1996.

[56] T. De Putter, A. Bernard, A. Perruchot, D. Nicaise, C. Dupuis, "Low-temperature acid weathering in Newhaven, Sussex, United Kingdom, and its implication to theoretical modeling in radioactive waste-disposal sites", Clays Clay Miner., vol. 48, n² 2, pp.238-246. 2000.

[57] R. Ertus, "neoformations of halloysite in cryptokarsts oligomiocènes In the Sambre-Meuse (Belgium). Approach sedimentological, mineralogical and petrographic "PhD Thesis from the University of Paris-South Orsay (France) and the Polytechnic Faculty of Mons (Belgium), pp.177, 1990.

[58] H. C. Hegelson, J. M. Delaney, "H. W. Nesbitt, D. K. Bird, Summary and critique of thermodynamic properties of rock-forming minerals Amer". J. Sci., (278A), pp 1-229, 1978.

[59] A. Inoue, M. Aoki, In situ growing kaolinite under hydrothermal conditions of Ohyunuma explosion crater lake, Hokkaido, Japan. Proc. $11^{\text {th }}$ Intern. Clay Conf Ottawa, 673-680, 1999.

[60] A. Inoue, M. Aoki, H. Ito, Mineralogy of Ohyunuma explosion crater lake, Hokkaido, Japan. Part 2; dynamics of kaolinite formation (Pers. Comm), 2002. 